\title{
GCU
}

Glasgow Caledonian

University

University for the Common Good

\section{Sustainable value creation? Entrepreneurial orientations in the football industry}

Bull, Mike; Whittam, Geoffrey

Published in:

International Journal of Entrepreneurial Behaviour and Research

DOI:

10.1108/IJEBR-07-2020-0498

Publication date:

2020

Document Version

Author accepted manuscript

Link to publication in ResearchOnline

Citation for published version (Harvard):

Bull, M \& Whittam, G 2020, 'Sustainable value creation? Entrepreneurial orientations in the football industry', International Journal of Entrepreneurial Behaviour and Research, vol. 27, no. 1, pp. 27-44.

https://doi.org/10.1108//JEBR-07-2020-0498

\section{General rights}

Copyright and moral rights for the publications made accessible in the public portal are retained by the authors and/or other copyright owners and it is a condition of accessing publications that users recognise and abide by the legal requirements associated with these rights.

Take down policy

If you believe that this document breaches copyright please view our takedown policy at https://edshare.gcu.ac.uk/id/eprint/5179 for details of how to contact us. 


\section{GCU}

Glasgow Caledonian

University

University for the Common Good

\section{Sustainable Value Creation? Entrepreneurial orientations in the football industry.}

Whittam, Geoffrey; Bull, Mike

Published in:

International Journal of Entrepreneurial Behaviour and Research

Publication date:

2020

Link to publication in ResearchOnline

Citation for published version (Harvard):

Whittam, G \& Bull, M 2020, 'Sustainable Value Creation? Entrepreneurial orientations in the football industry.', International Journal of Entrepreneurial Behaviour and Research.

\section{General rights}

Copyright and moral rights for the publications made accessible in the public portal are retained by the authors and/or other copyright owners and it is a condition of accessing publications that users recognise and abide by the legal requirements associated with these rights.

Take down policy

If you believe that this document breaches copyright please view our takedown policy at https://edshare.gcu.ac.uk/id/eprint/5179 for details of how to contact us. 


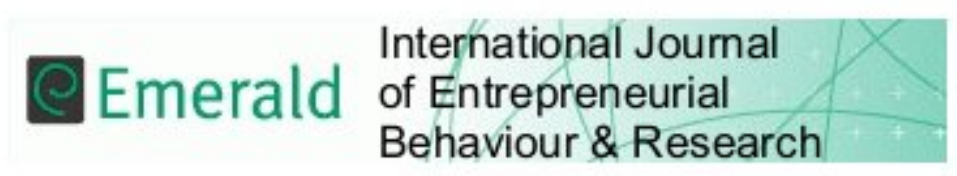

\section{Sustainable Value Creation? Entrepreneurial orientations in the football industry.}

\begin{tabular}{|r|l|}
\hline Journal: & International Journal of Entrepreneurial Behavior \& Research \\
\hline Manuscript ID & IJEBR-07-2020-0498.R1 \\
\hline Manuscript Type: & Research Paper \\
\hline Keywords: & Entrepreneurs, Entrepreneurial orientation, Entrepreneurship, Ownership \\
\hline \multicolumn{2}{|l}{} \\
\hline
\end{tabular}

\section{SCHOLARONE \\ Manuscripts}




\section{Sustainable Value Creation? Entrepreneurial orientations in the football industry.}

\section{Structured abstract}

Purpose - In this paper we investigate precarious value creation in English football clubs. We examine strategic, economic, cultural and social capital to analyse the orientations of legal owners of football clubs (entrepreneurs) and the implications for moral owners (the fans). Our research question is not if entrepreneurs create value - but whether the value created is productive or destructive?

Design/methodology/approach - The research design is a case study of the professional football industry, specifically 44 football clubs in the top two professional divisions in England, namely the English Premier League and The English Football League Championship. Our methodology is secondary textual data. Our approach is to examine official club statements, triangulated with regional and national press reports, fan accounts and narratives from published artefacts; fan blogs and websites.

Findings - The 'opening up' of the professional football industry in England to market forces in 1983 has subsequently attracted entrepreneurs that use football clubs as artefacts to pursue other business interests. Over-grazing on strategic and economic capital at the expense and exploitation of social and cultural capital exists. As entrepreneurial opportunities to exploit a football club's assets becomes more apparent, the unique relationship between club and fan is being strained. We observe detachment, disenchantment and protest.

Research limitations/implications - The data we sought for this study design was necessarily in the public domain and therefore drawn from secondary sources. The scope was English football and the top two divisions, thus the findings are context specific to that region and level.

Practical implications - For policy, we call for a new government inquiry into football ownership in English football, re-examining heritage, purpose and value creation.

Social implications - Football fans are the majority stakeholder in the football industry but are underrepresented in English football because of the private ownership of football clubs. Fans are however a barometer for how their owners are acting as custodianship of their clubs and if the value created by entrepreneurs is productive or exploitative.

Originality/value - This paper has value in drawing attention to this unique and ignored industry from an entrepreneurship perspective, provoking a call for further research to explore this phenomenon. Sustainable value creation may be a useful framework for further research in this and other industries.

Keywords: Entrepreneurs, Football Clubs, Fans, Capital, Value

Article Type: Research paper

Disclosure statement: Funding: This study did not involve any funding. No financial interest or benefit has arisen from the research in this paper. 


\section{Introduction}

It has long been recognised that professional football has become more than a game, it is a business and 'big business' at that - with an estimated worth of over $£ 10$ billion to the UK economy. Within England this transformation from 'a sport' to 'a business' can be traced back to the 'opening up' of football clubs to market forces and PLC status, which can be dated to 1983 when entrepreneurs Paul Bobroff and Irvin Scholar (the owners of Tottenham Hotspur FC), floated Tottenham on the Stock Exchange (Michie, 1999). The establishment of clubs as PLCs allowed the circumvention of 'Rule 34'. Rule 34 of the Football Association's Articles of Association prohibited Directors of Football Clubs from profiteering from a club by imposing maximum dividend payouts to Club Directors. Furthermore, the rule also stated that in the event of a club folding the assets would have to go to other sporting institutions. To all intents and purposes, English football clubs pre-1983 were social enterprises. Bobroff and Scholar's endeavours have changed football. Post-83 football ownership in England, provides opportunities for 'entrepreneurial activity' and there has been no shortage of entrepreneurs from around the globe seizing this opportunity, as we seek to highlight in this paper.

The professional football industry is unique, in that the main consumers of the product - the fans are co-creators of the product; by fandom, heritage, rituals, the wearing of the club colours, attending and generating an atmosphere at games, buying merchandise, and engaging with their respective clubs, for example, through fans forums (Brown, 2008; Numerato, 2015; Pongsakornrungsilp and Schroeder, 2011). Fans talk about football clubs as their club, they identify themselves as being more attached to their club than players, managers and owners - who all come and go; the fans are the ones who remain. Margalit (2008) goes as far as to suggest fans are a constitutive attribute of the club, arguing the concept of 'property as belonging' - therefore the interests of the community of fans merit protection through the recognition of the fans' property interest in a club. Similarly, Hassan and Hamil (2010) use the term 'fan equity' - observing fans as a club's unique artefact. Kennedy (2012) adds that football has for hundreds of thousands of fans been a vital part of the fabric of society, fans he argues, have an identity as 'moral' owners of their football clubs, which adds to the idiosyncratic nature of football club ownership and this industry.

Whilst there is a growing interest on the governance and ownership of football clubs in the sport literature there has been little focus from an entrepreneurial perspective. This paper seeks to contribute to this knowledge gap by analysing the football industry through an entrepreneurial lens. The relationship between the entrepreneurs and the fans of clubs is the dimension we are exploring in this under researched field of entrepreneurship. We draw on secondary textual data of regional and national press reports, fan opinions and reactions from published artefacts (from independent websites) and triangulated with official club information on football clubs from the English Premier League (hereafter EPL) and the FA English Football League Championship (hereafter EFLC) to evaluate each club in our case sample within the industry. We gain insight of "entrepreneurship as practice" (Johannison, 2011; McMullen and Dimov, 2013; Steyaert, 2007) examining entrepreneurs by means of Groen et al.'s (2008) conceptual framework of "sustainable value creation", which necessitates obtaining an equilibrium of four capitals; economic, strategic, cultural and social to 
achieve sustainable value creation (Groen et al. 2008). We use the model to highlight tensions between the two main co-producers of the product of football, which we think has an impact on the dis/equilibrium of individual clubs. We draw attention to different orientations of legal owners (entrepreneurs) and their responsibility to their club's moral owners (fans), classifying entrepreneurs into four categories; (i) Local Orientation; entrepreneurs that share the same cultural heritage as fans, ie; of UK origin, (ii) Fan Orientation; entrepreneurs that are themselves fans of the club they own, (iii) Investor Orientation; owners that are international entrepreneurs with economic interests and (iv) political orientation; international entrepreneurs that are using clubs as a vehicle for global/strategic interests). Our findings indicate some clubs in equilibrium, where the entrepreneur's interests are aligned with their fans, whilst other clubs are in disequilibrium, where an imbalance of interests is evident - with detachment, disenchantment and protest by the fans, as they feel a sense of injustice and exploitation. We find that it is not a given that entrepreneurs who are local, or fans of a club themselves, satisfy their fans interests - and more intriguingly, it is not a given that entrepreneurs with investor and political interests alienate a club's fans in all instances. However, disequilibrium is more commonplace where an investor orientation exists. We further suggest a longitudinal view shows that there is an ebb and flow of a club's equilibrium that is perpetuated by the frequent churn of ownership of many professional football clubs in the period since 1983, as this appears an unstable and fluid dynamic in this industry.

The paper is divided into five parts. Firstly, the literature review examines entrepreneurship literature towards identifying a theoretical framework. We then consider aspects of the football literature. Secondly, we present our methodology. Thirdly, we analyse the 44 clubs in the top two professional divisions of the English football pyramid. Fourthly, we address our research question by way of findings and discussion. We finally conclude, fleshing out the main aims and interpretations of the research in this article, highlighting that value is a contested concept in the business of football. We therefore call for a closer inspection and acknowledgment of entrepreneurship in professional football.

\section{Entrepreneurship theory and sustainable value creation}

It has become recognised that 'enterprise', 'entrepreneurship' and 'the entrepreneur' has come to mean more than an activity of the establishment of a new business by an individual person leading to profit maximisation. Typical examples of defining an entrepreneur are... "A person who habitually creates and innovates to build something of recognised value around perceived opportunities" (Bolton and Thompson, 2004, p. 16, [emphasis added]). Or as Burns (2016, p. 10) states "entrepreneurs create value by exploiting some form of change - either shifting resources or, more directly, improving productivity" (emphasis added). Whilst McDougall and Oviatt (2000) define international entrepreneurship as a combination of innovation and risk-seeking with the intention of creating value for an organisation. These definitions are interesting, in the sense that they all talk about the creation of value. In their theoretical model Bolton and Thompson argue that what entrepreneurs do in creating value is attaining capital, which can take a variety of forms, they specifically identify "financial, social and aesthetic" capital. Within these definitions there is a sense of entrepreneurship as doing, a practice based activity that makes things happen. We follow Gross and Geiger (2017) to record 
entrepreneurial practice as critical incidents, in that we identify conflict between owners and fans as an on-going evolutionary process. In essence, practices and their contexts (Welter, 2011) are interdependent and mutually shaping (Garud et al., 2014; Geiger and Kelly, 2014). Practice itself suggests there is a practice, (emphasis added) (Feldman and Orlikowski, 2011) leading to stability because practices are socially shared and agreed upon, yet through time they "contain the seeds of constant change" (Warde, 2005, p. 141). This idea is articulated by Johannisson (2011), who suggests we still have limited understanding of what precisely entrepreneurs actually do. In Hammerschmidt, et al.'s (2020) study into the entrepreneurial orientations of football clubs, a focus on innovation and opportunity exploitation as the practice of sport entrepreneurs concludes that an entrepreneurial orientation has a positive impact on financial and sporting performance. In calling for further research they acknowledge the need to enrich our understanding of entrepreneurship in the sporting context. This paper contributes to this knowledge deficit. A practice ontology, as Johannisson (2014) has recently argued, allows researchers to study both the resilience of practices to change as well as the emergence of new practices. In focussing on what entrepreneurs do, we are reminded of Baumol's influential paper. Baumol (1996) specifically argues that not all activities undertaken by entrepreneurs is productive....

"If entrepreneurs are defined simply to be persons who are ingenious and creative in finding ways that add to their own wealth, power and prestige, then it is to be expected that not all of them will be overly concerned with whether an activity that achieves these goals adds much or little to the social product or, for that matter, even whether it is an actual impediment to production (this notion goes back at least to Veblen (1904)" (Baumol, 1996, p.6).

Whilst Baumol is specifically looking at the macro-economy and offering hypothesis to gain an understanding from an historical perspective as to why certain societies 'faltered' in terms of their economic prowess, the central thesis can be applied to other contexts. Thus, whilst the practice of entrepreneurs doing entrepreneurship may create capital or add value, not all members of society benefit from this creation indeed some members of society may challenge whether what has been created is indeed capital or value, or whether there has been exploitation. In explaining the concept of value, Kornberger (2017), suggests that value is a plural construct, stating that even economic value is embedded in cultural, social and other values. He continues to acknowlede that the values that exist outside of an organisation, can be utilized by a firm to "bring them "inside" - making them part of its "cultural toolkit". In the football industry we contend that, some entrepreneurs in the words of Baumol (1996), engage in "unproductive entrepreneurial activity". This can be attributed to what Keller (2007) summarises as a growing trend in modern business theory, seen through a neoclassical economic paradigm, which has a moral code of business based on self-interest, efficiency and outcome. Thus, legitimising commodification and profit maximising behaviour. Keller goes on to suggest that this paradigm has left society with a negative ethics base - based on exploitation and 'greed'. This negative ethical base can be at an individual or societal level and in nature and the earth's resources, thus, where there is exploitation, there are the exploiters and the exploited. 
Exploitation is exemplified by some entrepreneurs within professional football. We suggest in the next section that within professional football there are periods of tranquillity, equilibrium, which are interspersed with periods of detachment, disenchantment and protest - a dis-equilibrium precipitated by the exploitative practices of entrepreneurs. Whilst football governing bodies have certain regulations applicable to the running of football clubs (called the Fit and Proper Person Test), these tend to be ineffective in curbing unscrupulous entrepreneurial behaviour, as we highlight in this paper. Similarly, to Baumol, Kets de Vries (1985) and Wright and Zahra (2011) concur, they put that entrepreneurs might be difficult and unpredictable, they like being in control and do not necessarily consider those outside of their mindset, they may indeed be filled with delusions of grandeur, power and bloody-mindedness, misusing their stature in organisations to subvert societal codes via transgressive practices.

What we take from Baumol, Keller, Kets de Vries and Wright and Zahra is that not all value creation is adding to the social product, and indeed fans of football clubs could be seen as an impediment to the production interests of the entrepreneur that may be filled with delusions and unpredictability. Yet, as stated, Kornberger outlines value as being embedded in culture and society and giving attention to these aspects could add value through bringing inside and adding to a cultural toolkit. In this regard the work of Groen (2005) and Groen et al. (2008) is particularly pertinent (See Figure 1). In unpacking the recognition of value and capital, Groen (2005) and Groen et al. (2008) outline that building sustainable businesses requires an understanding of, and balance of, four key aspects that pertain to value creation - they are strategic, economic, cultural and social capital. In summary the four capitals are:

- (1). Strategic capital - This aspect relates to the deployment of tactics.

- (2). Cultural capital - This aspect relates to utilising belonging to a particular culture and shared heritage.

- (3). Economic capital - This aspect relates to the focus on finance and capital that can be harnessed to recognise, prepare and exploit opportunities.

- (4). Social capital - This aspect relates to community; networks, ties, bonds, and relationships that can be galvanised to support action.

Whilst Groen et al. (2008) apply their model to a start-up firm, we utilise their spirit of research design and adapt the model for conceptualising the professional football industry in England. Their model highlights the potential tensions which exist for the entrepreneurial firm by identifying the necessity of maintaining a balance between the four capitals which compete and contribute to sustained value creation over both the short and long term. The attraction of Groen's model is that it offers the opportunity to perform a "multi-dimensional analysis" which is pertinent for our study. 
Figure 1: The Four Capitals of sustainable value creation (author's own Figure, adapted and developed from Groen et al. 2008, p. 63)

[Figure 1 added here]

The four capitals approach is of particular relevance because it raises the question of interdependencies and inter-relations (as demonstrated in the arrows in Figure 1), in football clubs these are key in determining the role of self-interest (tactics), efficiency (finance) and the exploitation of custom and tradition (heritage), questioning the raison d'etre of the clubs (community) and their value. In this literature review we garner a sense that entrepreneurs create value, but as Baumol's argument goes, not all value creation is productive to everyone. Our main investigation is to explore the research question - not if entrepreneurs create value, but whether value is productive or destructive to the sustainability of football clubs and consequently the leagues and the industry itself? In analysing entrepreneurship in action in this paper we are exploring the orientations of entrepreneurs within the football industry, which the change in the regulatory framework, in 1983 (namely the circumvention of Rule 34) provided as the entrepreneurial opportunity in this industry, which we explain in the following section.

\section{Football and the new breed of entrepreneurs}

The traditional view of the Football Club owner is one of custodian, club fan and local entrepreneur 'giving something back' to the community. The narrative being couched as guardianship, stewardship or custodianship. These entrepreneurs are consequently termed insiders, they share geographical, fan and heritage with their club (Dimitropoulos et al., 2016; Hamil and Walters, 2010; Kennedy, 2013; Kennedy and Kennedy, 2010). The fan was king, the entrepreneur in providing the funds in the best interests of the club to do their best and compete in their league, aiming for the club to be as 
successful as they can be, given the entrepreneur's extensive, or limited, wealth. Financial returns in this model are piece-meal if at all.

Morrow (2013, p. 297), drawing on Hamil et al. (2000 and 2001); Morrow (2003) and Nash (2000) suggests "football has always been and continues to be a social business; economic in basis, but social in nature". Kennedy (2012) argues that football has for hundreds of thousands of fans been a vital part of the fabric of society. However, he continues to argue 'The not-for-profit, 'one game' principle held sway for a century prior to its dismantling and the opening up of football to market forces as another 'branch of the entertainment industry' removing sentiment from an object of social purpose to one of commodification (Kennedy, 2012, p. 411). King (1997) argues that a football club was in many ways a public utility, like a library, suggesting the entrepreneur's role was a type of 'bourgeois philanthropy' (1997, p. 228), he illustrates;

"When David Dein, [... became] involved in football, acceded to the board of directors at Arsenal in 1983, Hill-Wood [the then Chairman of Arsenal FC] commented, "Some rich men like to buy fast cars, yachts, and racehorses, but Dein is more interested in Arsenal. I'm delighted he is but I think he's crazy. To all intents and purposes, it's dead money" (King, 1997, p. 228)

David Dein was a local, he was and is also an Arsenal fan, an insider. What the example of Dein highlights is that, as Hill-Wood suggests, entrepreneurs are rich men (some are women too!) that have money to spend on hobbies, without financial return. Hill-Wood's call was however a little premature, Dein was either crazy or very astute! He bought $16.6 \%$ of Arsenal for £292,000 in 1983 and sold $14.58 \%$ for $£ 75$ million in $2007^{1}$.

As seen in this example, Dein realised a significant return. In post 1983 football the revenue streams in English football have risen, it has become possible to make significant financial gains out of investment in professional football clubs, and therefore there is an appeal to entrepreneurs to invest and capitalise on the opportunities to exploit the market hegemony. The zeitgeist in modern, global, football has shifted to a new breed of entrepreneur as the game's commercial age has taken a new twist (Hamil and Walters, 2010; Millward, 2013). Margalit (2008, p. 219) suggests; 'Modern football has become a battlefield between market and community, and where community is not able to prevail'. Morrow (2013, p. 297) adds, football as an economic activity has been normalised. Coupled with the governance changes established in 1983, profit seekers have entered into the ownership of clubs for financial [and non-financial] reasons beyond that of traditional owners. Millward (2013) explains the profit maximising appeal to entrepreneurs in four different ways; (i) deregulation of TV revenue streams (ii) using football as a vehicle to promote other business interests ${ }^{2}$ (iii) to float the club on overseas stock markets and (iv) to promote the club into the EPL (for global adoration).

\footnotetext{
${ }^{1}$ http://www.independent.co.uk/sport/football/premier-league/dein-will-lead-russian-bid-for-arsenal-after-selling-stake-463639.html

2 King 1997, uses the example of Newcastle United owner Hall, as a new entrepreneur that has significantly invested in the club and local infrastructure (shopping mall) as a local figurehead, with his own business interests beyond football that may potentially grow with the uplift to the city. The second example King uses is Gibson at Middlesborough, which has built an association with $\mathrm{ICl}$, as shirt sponsors - but also client to his own haulage firm. Both described as an integrated strategy.
} 
New entrepreneurs are now king, and whilst football is an attraction, there are different interests, the entrepreneur is utilizing and harnessing the club's profile for their own best interests (Numerato, 2014; Rohde and Breuer, 2017; Turner, 2014; Webber, 2017). Entrepreneurs now entering the game tend not to be local guardians, stewards or custodians, they do not share geographical links, they have no history and attachment to the club and they are investors, not fans, they are - outsiders (Millward, 2013; Webber, 2017). These entrepreneurs have fundamentally changed the legitimisation of postmodern football, creating a free market discourse and separation of alignment between fan and owner (Millward, 2013; Turner, 2014; Webber, 2017) often with negative consequences, that is unproductive entrepreneurship. A typical example of this can be found with the collapse in 2010 of Portsmouth Football Club, with debts of over $£ 60$ million, they are the first EPL club to enter administration, exposing issues within modern day English football that commentators and fans have long been aware of (see King, 1997). Morrow suggests that in recent times, with commercial interests in football clubs, pluralistic logic of conventional commercial profit maximisation has come to the fore. It is with this in mind that we analyse the football industry and seek to shed light from an entrepreneurship lens, identifying the interests of entrepreneurs and the implications this has on sustainable value creation of football clubs.

In the next section we outline our methodology, drawing on aspects of the literature review towards presenting our approach to this research investigation, prior to exploring the impact of entrepreneurs on specific clubs.

\section{Methodology}

Our methodology was a systematic case study approach (Stake, 1995) of a sub-section of the football industry, examining each of the 44 clubs in the top two divisions of professional football in England. We sought to explain, describe and explore phenomena, as outlined by Stake (1995) and Yin (2003). Our method was to explore secondary textual data (Easterby-Smith et al, 2018, Ridley-Duff and Bull, 2020 ) in order to capture a wide range of opinions readily available within the public domain. Secondary textual data capture is a non-responsive form of data collection, adopted to examining regional and national press reports, fan opinions and reactions from published artefacts (from independent websites) and triangulated with official club information on football clubs. Our aim was to understand owners and fans in each of the 44 football clubs in this sub-section of the industry which represents the pinnacle of English professional football. To add rigour to the process of our analysis, the cases were developed as follows: In the first phase, materials from official club websites were examined to identify the share capital structures of ownership in each club and read through official press releases about club legal owners, developing a descriptive narrative of each club (any changes of ownership were updated to this data set up to three months of submission of the paper). Appendix 1 presents the lengthy data we captured across all 44 clubs. In the second phase we searched for (national and local) news articles about relational issues - between entrepreneur and fan (both current and historical [covering a 10 year period), this second phase provided a barometer for opinion, given the fluidity of ownership and changing attitudes of fans the results provided a cultural contextual feel for a club, a feel for life. In doing so, we resonate with Raymond Williams $(1973,1977)$ work on 
'structure of feeling', whereby gaining a sense of a feel for a situation, looking at cultural context and taking a bird's eye view of a social landscape is sought. Meaning we gauged a feel for the disposition of a club, we sought to develop an understanding of the local cultural context in each club over a 10 year period. In the third phase we triangulated news articles with fans forums, independent fan groups websites and blogs to validify media reporting with protests, opinions, issues and concerns of fans that were in the public domain. A process of re-reading official statements, fan opinions and reporting in the press eventually reaching data saturation provided our overarching opinions on each of the club's owners and fans ${ }^{3}$. In the next section we explain how we operationalised the data in our analysis.

\section{Findings and Discussion}

Our methodology explained how we collected the data for our research. Appendix 1 provides the details of ownership and evidence of togetherness or detachment in a club's relationship between owners and fans. Here we discuss how we used the data that is presented in Appendix 1 to analyse each club. We present and discuss Tables 1, 2 and 3 and Figures 2 and 3. We analyse all 44 clubs relating to their division in their respected leagues, noting their share ownership structures (see Table $1,2$ and 3 ) and in more detail Appendix 1$)^{4}$.

We began our analysis by utilising Groen et al.'s (2008) theoretical framework to identify entrepreneurs of the clubs as having an orientation towards one of four categories (see Figures 2 and 3)5: (i) Fan Orientation as primarily equating to social capital (Dimitropoulos et al. 2016; Kennedy and Kennedy 2010), these owners are also fans of the clubs themselves - insiders - and therefore have the most potential to bridge, bond and have ties with all of their club's fans. (ii) Local Orientation as primarily equating to cultural capital (Margalit, 2008; Morrow, 2013), these owners share the same culture and heritage as geographically local fans ${ }^{6}$ (i.e.; UK based in this context - insiders). (iii) Investor Orientation as equating to economic capital (Hamil and Walters, 2010; Millward, 2013), these owners are involved to capitalise on the financial value of clubs and have no prior connection outsiders, and (iv) Political Orientation as equating to strategic capital (Breuer, 2017; Numerato, 2014; Rohde and Turner, 2014; Webber, 2017), these owners are tactical actors that have no prior connection with the club - outsiders. Their involvement goes beyond that of the value of the club itself. In taking sustainable value creation as important, we incorporate Margalit's (2008) concept of fans 'property of belonging', Kennedy's (2012) sentiments of fans as 'moral owners' and Hassan and Hamill's (2010) term 'fan equity' to analyse equilibrium by investigating if fans interests align with that of the entrepreneurs, as they are a barometer of their club's equilibrium. We took the representation

\footnotetext{
${ }^{3}$ We are aware that the opinions we gathered might not represent all fans, as fans themselves hold different opinions, yet we worked to gain a sense of the majority of an opinion.

${ }^{4}$ Football club ownership is in constant change, we therefore are as up to date as we can be as at June $1{ }^{\text {st }} 2020$. Since this date WAFC has changed ownership and gone into liquidation.

${ }^{5}$ We acknowledge that some entrepreneurs may straddle more than one orientation, for clarity we positioned against their primary orientation.

${ }^{6}$ Not disputing that fans of clubs in England come from all over the world, but the geographically based fan in the specific locality is the primary fan base we are referring to.
} 
of structure of feeling (from our methodology), giving a rudimentary colour code (white, grey or black) (see Tables 1, 2 and 3) to adjudicate alignment;

- (i) white for 'Equilibrium. No reports of detachment, disenchantment or protest; interests of the entrepreneur and fans aligned' to ascertain that equilibrium is in balance;

- (ii) grey for 'Equilibrium. Yet, recent history of detachment, disenchantment and protest to ascertain that equilibrium has not always been aligned and;

- (iii) black for 'Disequilibrium. Current detachment, disenchantment and protest.' to ascertain that there is disequilibrium in the club.

Following Baumol's (1996) line of inquiry into productive and unproductive entrepreneurship, we add an indicative score of;

- (i) $\mathbf{E}=+\mathbf{+ 1}$ for productive entrepreneurship (equilibrium), represented in the Tables 1, 2 and 3 as equilibrium.

- (ii) $\mathbf{E}=\mathbf{0}$ for clubs where there has been both productive and unproductive entrepreneurship in the Tables 1, 2 and 3 and

- (iii) $\mathbf{E}=-\mathbf{- 1}$ for unproductive entrepreneurship (disequilibrium), represented in the Tables 1, 2 and 3 as disequilibrium. 


\begin{tabular}{|c|c|c|c|c|c|}
\hline No & $\begin{array}{l}\text { EPL Club (by League } \\
\text { Position) }\end{array}$ & $\begin{array}{l}\text { Majority Orientation } \\
\text { Cluster }\end{array}$ & $\begin{array}{l}\text { Entrepreneur } \\
\text { Type }\end{array}$ & Equilibrium/Disequilibrium & Coding \\
\hline 1 & Liverpool FC (LFC) & $\begin{array}{l}\text { Economic Capital / } \\
\text { Investor Orientation }\end{array}$ & Outsider & $\begin{array}{l}\text { Equilibrium. Yet, recent history of detachment, } \\
\text { disenchantment and protest. }\end{array}$ & $\begin{array}{l}\text { Grey } \\
\mathrm{E}=0\end{array}$ \\
\hline 2 & Manchester City FC (MCFC) & $\begin{array}{l}\text { Strategic Capital / } \\
\text { Political Orientation }\end{array}$ & Outsider & $\begin{array}{l}\text { Equilibrium. Yet, recent history of detachment, } \\
\text { disenchantment and protest. }\end{array}$ & $\begin{array}{l}\text { Grey } \\
\mathrm{E}=0\end{array}$ \\
\hline 3 & $\begin{array}{l}\text { Manchester United FC } \\
\text { (MUFC) }\end{array}$ & $\begin{array}{l}\text { Economic Capital / } \\
\text { Investor Orientation }\end{array}$ & Outsider & $\begin{array}{l}\text { Disequilibrium. Detachment, disenchantment and } \\
\text { protest. }\end{array}$ & $\begin{array}{l}\text { Black } \\
\mathrm{E}=-1\end{array}$ \\
\hline 4 & Chelsea FC (CFC) & $\begin{array}{l}\text { Strategic Capital / } \\
\text { Political Orientation }\end{array}$ & Outsider & $\begin{array}{l}\text { Equilibrium. No reports of detachment, } \\
\text { disenchantment or protest. }\end{array}$ & White \\
\hline 5 & Leicester City FC (LCFC) & $\begin{array}{l}\text { Economic Capital / } \\
\text { Investor Orientation }\end{array}$ & Outsider & $\begin{array}{l}\text { Equilibrium. Yet, recent history of detachment, } \\
\text { disenchantment and protest. }\end{array}$ & $\begin{array}{l}\text { Grey } \\
E=0\end{array}$ \\
\hline 6 & $\begin{array}{l}\text { Tottenham Hotspur FC } \\
\text { (THFC) }\end{array}$ & $\begin{array}{l}\text { Social Capital / Fan } \\
\text { Orientation }\end{array}$ & Insider & $\begin{array}{l}\text { Disequilibrium. Detachment, disenchantment and } \\
\text { protest. }\end{array}$ & $\begin{array}{l}\mathrm{c}-0 \\
\text { Black } \\
\mathrm{E}=-1\end{array}$ \\
\hline 7 & $\begin{array}{l}\text { Wolverhampton Wanderers } \\
\text { FC (WWFC) }\end{array}$ & $\begin{array}{l}\text { Strategic Capital / } \\
\text { Political Orientation }\end{array}$ & Outsider & $\begin{array}{l}\text { Equilibrium. Yet, recent history of detachment, } \\
\text { disenchantment and protest. }\end{array}$ & $\begin{array}{l}\text { Grey } \\
\mathrm{E}=0\end{array}$ \\
\hline 8 & Arsenal FC (AFC) & $\begin{array}{l}\text { Economic Capital / } \\
\text { Investor Orientation }\end{array}$ & Outsider & $\begin{array}{l}\text { Disequilibrium. Detachment, disenchantment and } \\
\text { protest. }\end{array}$ & $\begin{array}{l}\text { Black } \\
\mathrm{E}=-1\end{array}$ \\
\hline 9 & Sheffield United FC (SUFC) & $\begin{array}{l}\text { Strategic Capital / } \\
\text { Political Orientation }\end{array}$ & Outsider & $\begin{array}{l}\text { Equilibrium. Yet, recent history of detachment, } \\
\text { disenchantment and protest. }\end{array}$ & $\begin{array}{l}\text { Grey } \\
\mathrm{E}=0\end{array}$ \\
\hline 10 & Burnley FC (BFC) & $\begin{array}{l}\text { Social Capital / Fan } \\
\text { Orientation }\end{array}$ & Insider & $\begin{array}{l}\text { Equilibrium. No reports of detachment, } \\
\text { disenchantment or protest. }\end{array}$ & $\begin{array}{l}\text { White } \\
E=+1\end{array}$ \\
\hline 11 & Southampton FC (SFC) & $\begin{array}{l}\text { Economic Capital/ } \\
\text { Investor Orientation }\end{array}$ & Outsider & $\begin{array}{l}\text { Disequilibrium. Detachment, disenchantment and } \\
\text { protest. }\end{array}$ & $\begin{array}{l}\text { Black } \\
\mathrm{E}=-1\end{array}$ \\
\hline 12 & Everton FC (EFC) & $\begin{array}{l}\text { Economic Capital / } \\
\text { Investor Orientation }\end{array}$ & Outsider & $\begin{array}{l}\text { Equilibrium. Yet, recent history of detachment, } \\
\text { disenchantment and protest. }\end{array}$ & $\begin{array}{l}\text { Grey } \\
E=0\end{array}$ \\
\hline 13 & $\begin{array}{l}\text { Newcastle United FC } \\
\text { (NUFC) }\end{array}$ & $\begin{array}{l}\text { Cultural Capital / } \\
\text { Local Orientation }\end{array}$ & Insider & $\begin{array}{l}\text { Disequilibrium. Detachment, disenchantment and } \\
\text { protest. }\end{array}$ & $\begin{array}{l}\mathrm{C}-\mathrm{U} \\
\mathrm{Black} \\
\mathrm{E}=-1\end{array}$ \\
\hline 14 & Crystal Palace FC (CPFC) & $\begin{array}{l}\text { Economic Capital / } \\
\text { Investor Orientation }\end{array}$ & Outsider & $\begin{array}{l}\text { Disequilibrium. Detachment, disenchantment and } \\
\text { protest. }\end{array}$ & $\begin{array}{l}\text { Black } \\
\mathrm{E}=-1\end{array}$ \\
\hline 15 & $\begin{array}{l}\text { Brighton \& Hove Albion FC } \\
\text { (B\&HAFC) }\end{array}$ & $\begin{array}{l}\text { Social Capital / Fan } \\
\text { Orientation }\end{array}$ & Insider & $\begin{array}{l}\text { Equilibrium. No reports of detachment, } \\
\text { disenchantment or protest. }\end{array}$ & $\begin{array}{l}\text { White } \\
\mathrm{E}=+1\end{array}$ \\
\hline 16 & $\begin{array}{l}\text { West Ham United FC } \\
\text { (WHUFC) }\end{array}$ & $\begin{array}{l}\text { Social Capital / Fan } \\
\text { Orientation }\end{array}$ & Insider & $\begin{array}{l}\text { Disequilibrium. Detachment, disenchantment and } \\
\text { protest. }\end{array}$ & $\begin{array}{l}\text { Black } \\
\mathrm{E}=-1\end{array}$ \\
\hline 17 & Aston Villa FC (AVFC) & $\begin{array}{l}\text { Economic Capital/ } \\
\text { Investor Orientation }\end{array}$ & Outsider & $\begin{array}{l}\text { Equilibrium. Yet, recent history of detachment, } \\
\text { disenchantment and protest. }\end{array}$ & $\begin{array}{l}\text { Grey } \\
\mathrm{E}=0\end{array}$ \\
\hline 18 & AFC Bournemouth (AFCB) & $\begin{array}{l}\text { Economic Capital/ } \\
\text { Investor Orientation }\end{array}$ & Outsider & $\begin{array}{l}\text { Equilibrium. No reports of detachment, } \\
\text { disenchantment or protest. }\end{array}$ & $\begin{array}{l}\text { White } \\
\mathrm{E}=+1\end{array}$ \\
\hline 19 & Watford FC (WFC) & $\begin{array}{l}\text { Economic Capital / } \\
\text { Investor Orientation }\end{array}$ & Outsider & $\begin{array}{l}\text { Equilibrium. Yet, recent history of detachment, } \\
\text { disenchantment and protest. }\end{array}$ & $\begin{array}{l}\text { Grey } \\
\mathrm{E}=0\end{array}$ \\
\hline 20 & Norwich City FC (NCFC) & $\begin{array}{l}\text { Social Capital / Fan } \\
\text { Orientation }\end{array}$ & Insider & $\begin{array}{l}\text { Equilibrium. No reports of detachment, } \\
\text { disenchantment or protest. }\end{array}$ & $\begin{array}{l}\text { White } \\
E=+1\end{array}$ \\
\hline
\end{tabular}

Table 1: Evaluating Equilibrium/Disequilibrium in the EPL in final league position order, season 2019/20. 


\begin{tabular}{|c|c|c|c|c|c|}
\hline No & $\begin{array}{l}\text { EFLC Club (by League } \\
\text { Position) }\end{array}$ & $\begin{array}{l}\text { Majority Orientation } \\
\text { Cluster }\end{array}$ & $\begin{array}{l}\text { Entrepreneur } \\
\text { Type }\end{array}$ & Equilibrium/Disequilibrium & Coding \\
\hline 1 & Leeds United FC (LUFC) & $\begin{array}{l}\text { Economic Capital/ } \\
\text { Investor Orientation }\end{array}$ & Outsider & $\begin{array}{l}\text { Equilibrium. Yet, recent history of detachment, } \\
\text { disenchantment and protest. }\end{array}$ & $\begin{array}{l}\text { Grey } \\
E=0\end{array}$ \\
\hline 2 & $\begin{array}{l}\text { West Bromwich Albion FC } \\
\text { (WBAFC) }\end{array}$ & $\begin{array}{l}\text { Strategic Capital / } \\
\text { Political Orientation }\end{array}$ & Outsider & $\begin{array}{l}\text { Equilibrium. No reports of detachment, } \\
\text { disenchantment or protest. }\end{array}$ & $\begin{array}{l}\text { White } \\
\mathrm{E}=+1\end{array}$ \\
\hline 3 & Brentford FC (BrentFC) & $\begin{array}{l}\text { Cultural Capital / Fan } \\
\text { Orientation }\end{array}$ & Insider & $\begin{array}{l}\text { Equilibrium. No reports of detachment, } \\
\text { disenchantment or protest. }\end{array}$ & $\begin{array}{l}\text { White } \\
\mathrm{E}=+1\end{array}$ \\
\hline 4 & Fulham FC (FFC) & $\begin{array}{l}\text { Economic Capital/ } \\
\text { Investor Orientation }\end{array}$ & Outsider & $\begin{array}{l}\text { Disequilibrium. Detachment, disenchantment and } \\
\text { protest. }\end{array}$ & $\begin{array}{l}\text { Black } \\
\mathrm{E}=-1\end{array}$ \\
\hline 5 & Cardiff City FC (CCFC) & $\begin{array}{l}\text { Economic Capital / } \\
\text { Investor Orientation }\end{array}$ & Outsider & $\begin{array}{l}\text { Disequilibrium. Detachment, disenchantment and } \\
\text { protest. }\end{array}$ & $\begin{array}{l}\text { Black } \\
E=-1\end{array}$ \\
\hline 6 & Swansea City AFC (SCAFC) & $\begin{array}{l}\text { Economic Capital / } \\
\text { Investor Orientation }\end{array}$ & Outsider & $\begin{array}{l}\text { Disequilibrium. Detachment, disenchantment and } \\
\text { protest. }\end{array}$ & $\begin{array}{l}\text { Black } \\
\mathrm{E}=-1\end{array}$ \\
\hline 7 & $\begin{array}{l}\text { Nottingham Forest FC } \\
\text { (NFFC) }\end{array}$ & $\begin{array}{l}\text { Economic Capital / } \\
\text { Investor Orientation }\end{array}$ & Outsider & $\begin{array}{l}\text { Equilibrium. Yet, recent history of detachment, } \\
\text { disenchantment and protest. }\end{array}$ & $\begin{array}{l}\text { Grey } \\
E=0\end{array}$ \\
\hline 8 & Millwall FC (MillFC) & $\begin{array}{l}\text { Economic Capital / } \\
\text { Investor Orientation }\end{array}$ & Outsider & $\begin{array}{l}\text { Equilibrium. No reports of detachment, } \\
\text { disenchantment or protest. }\end{array}$ & White \\
\hline 9 & $\begin{array}{l}\text { Preston North End FC } \\
\text { (PNEFC) }\end{array}$ & $\begin{array}{l}\text { Cultural Capital / Fan } \\
\text { Orientation }\end{array}$ & Insider & $\begin{array}{l}\text { Equilibrium. No reports of detachment, } \\
\text { disenchantment or protest. }\end{array}$ & $\begin{array}{l}\text { White } \\
E=+1\end{array}$ \\
\hline 10 & Derby County FC (DCFC) & $\begin{array}{l}\text { Cultural Capital / Fan } \\
\text { Orientation }\end{array}$ & Insider & $\begin{array}{l}\text { Equilibrium. Yet, recent history of detachment, } \\
\text { disenchantment and protest. }\end{array}$ & $\begin{array}{l}\text { Grey } \\
\mathrm{E}=0\end{array}$ \\
\hline 11 & Blackbum R & $\begin{array}{l}\text { Economic Capital/ } \\
\text { Investor Orientation }\end{array}$ & Outsider & $\begin{array}{l}\text { Disequilibrium. Detachment, disenchantment and } \\
\text { protest. }\end{array}$ & $\begin{array}{l}\text { Black } \\
\mathrm{E}=-1\end{array}$ \\
\hline 12 & Bristol City FC (BristCFC) & $\begin{array}{l}\text { Cultural Capital / Fan } \\
\text { Orientation }\end{array}$ & Insider & $\begin{array}{l}\text { Equilibrium. No reports of detachment, } \\
\text { disenchantment or protest. }\end{array}$ & $\begin{array}{l}\text { White } \\
\mathrm{E}=+1\end{array}$ \\
\hline 13 & $\begin{array}{l}\text { Queens Park Rangers FC } \\
\text { (QPRFC) }\end{array}$ & $\begin{array}{l}\text { Economic Capital / } \\
\text { Investor Orientation }\end{array}$ & Outsider & $\begin{array}{l}\text { Equilibrium. Yet, recent history of detachment, } \\
\text { disenchantment and protest. }\end{array}$ & $\begin{array}{l}\text { Grey } \\
\mathrm{E}=0\end{array}$ \\
\hline 14 & Reading FC (RFC) & $\begin{array}{l}\text { Economic Capital / } \\
\text { Investor Orientation }\end{array}$ & Outsider & $\begin{array}{l}\text { Equilibrium. Yet, recent history of detachment, } \\
\text { disenchantment and protest. }\end{array}$ & $\begin{array}{l}\text { Grey } \\
\mathrm{E}=0\end{array}$ \\
\hline 15 & Stoke City FC (SCFC) & $\begin{array}{l}\text { Cultural Capital / Fan } \\
\text { Orientation }\end{array}$ & Insider & $\begin{array}{l}\text { Equilibrium. Yet, recent history of detachment, } \\
\text { disenchantment and protest. }\end{array}$ & $\begin{array}{l}\text { Grey } \\
\mathrm{E}=0\end{array}$ \\
\hline 16 & $\begin{array}{l}\text { Sheffield Wednesday FC } \\
\text { (SWFC) }\end{array}$ & $\begin{array}{l}\text { Economic Capital / } \\
\text { Investor Orientation }\end{array}$ & Outsider & $\begin{array}{l}\text { Disequilibrium. Detachment, disenchantment and } \\
\text { protest. }\end{array}$ & $\begin{array}{l}\text { Black } \\
\mathrm{E}=-1\end{array}$ \\
\hline 17 & Middlesbrough FC (MidFC) & $\begin{array}{l}\text { Cultural Capital / Fan } \\
\text { Orientation }\end{array}$ & Insider & $\begin{array}{l}\text { Equilibrium. No reports of detachment, } \\
\text { disenchantment or protest. }\end{array}$ & $\begin{array}{l}\text { White } \\
E=+1\end{array}$ \\
\hline 18 & $\begin{array}{l}\text { Huddersfield Town FC } \\
\text { (HTFC) }\end{array}$ & $\begin{array}{l}\text { Cultural Capital / Fan } \\
\text { Orientation }\end{array}$ & Insider & $\begin{array}{l}\text { Equilibrium. No reports of detachment, } \\
\text { disenchantment or protest. }\end{array}$ & $\begin{array}{l}\text { White } \\
E=+1\end{array}$ \\
\hline 19 & Luton Town FC (LTFC) & $\begin{array}{l}\text { Cultural Capital / Fan } \\
\text { Orientation }\end{array}$ & Insider & $\begin{array}{l}\text { Equilibrium. No reports of detachment, } \\
\text { disenchantment or protest. }\end{array}$ & $\begin{array}{l}\text { White } \\
E=+1\end{array}$ \\
\hline 20 & $\begin{array}{l}\text { Birmingham City FC } \\
\text { (BirmCFC) }\end{array}$ & $\begin{array}{l}\text { Strategic Capital / } \\
\text { Political Orientation }\end{array}$ & Outsider & $\begin{array}{l}\text { Disequilibrium. Detachment, disenchantment and } \\
\text { protest. }\end{array}$ & $\begin{array}{l}\text { Black } \\
\mathrm{E}=-1\end{array}$ \\
\hline 21 & Barnsley (BarnFC) & $\begin{array}{l}\text { Economic Capital / } \\
\text { Investor Orientation }\end{array}$ & Outsider & $\begin{array}{l}\text { Disequilibrium. Detachment, disenchantment and } \\
\text { protest. }\end{array}$ & $\begin{array}{l}\text { Black } \\
\mathrm{E}=-1\end{array}$ \\
\hline 22 & Charlton Athletic (CAFC) & $\begin{array}{l}\text { Economic Capital / } \\
\text { Investor Orientation }\end{array}$ & Outsider & $\begin{array}{l}\text { Disequilibrium. Detachment, disenchantment and } \\
\text { protest. }\end{array}$ & $\begin{array}{l}\text { Black } \\
\mathrm{E}=-1\end{array}$ \\
\hline 23 & Wigan Athletic FC (WAFC) & $\begin{array}{l}\text { Strategic Capital / } \\
\text { Political Orientation }\end{array}$ & Outsider & $\begin{array}{l}\text { Disequilibrium. Detachment, disenchantment and } \\
\text { protest. }\end{array}$ & $\begin{array}{l}\text { Black } \\
\mathrm{E}=-1\end{array}$ \\
\hline 24 & Hull City (HCFC) & $\begin{array}{l}\text { Cultural Capital / } \\
\text { Local Orientation }\end{array}$ & Insider & $\begin{array}{l}\text { Disequilibrium. Detachment, disenchantment and } \\
\text { protest. }\end{array}$ & $\begin{array}{l}\text { Black } \\
\mathrm{E}=-1\end{array}$ \\
\hline
\end{tabular}

Table 2: Evaluating Equilibrium/Disequilibrium in the ELFC in final league position order, season 2019/20. 


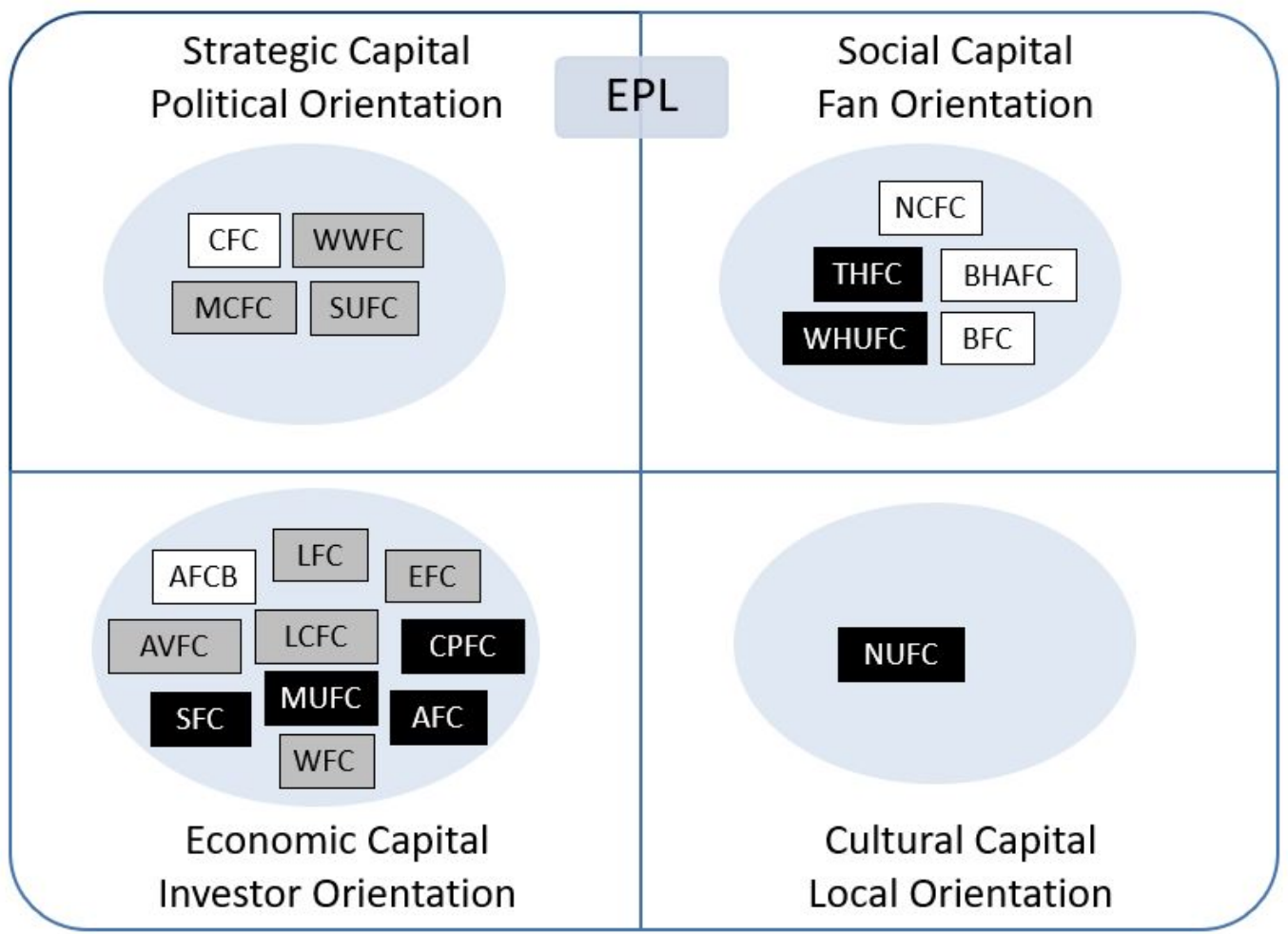

Figure 2: Orientation/Capital Mapping in the EPL.

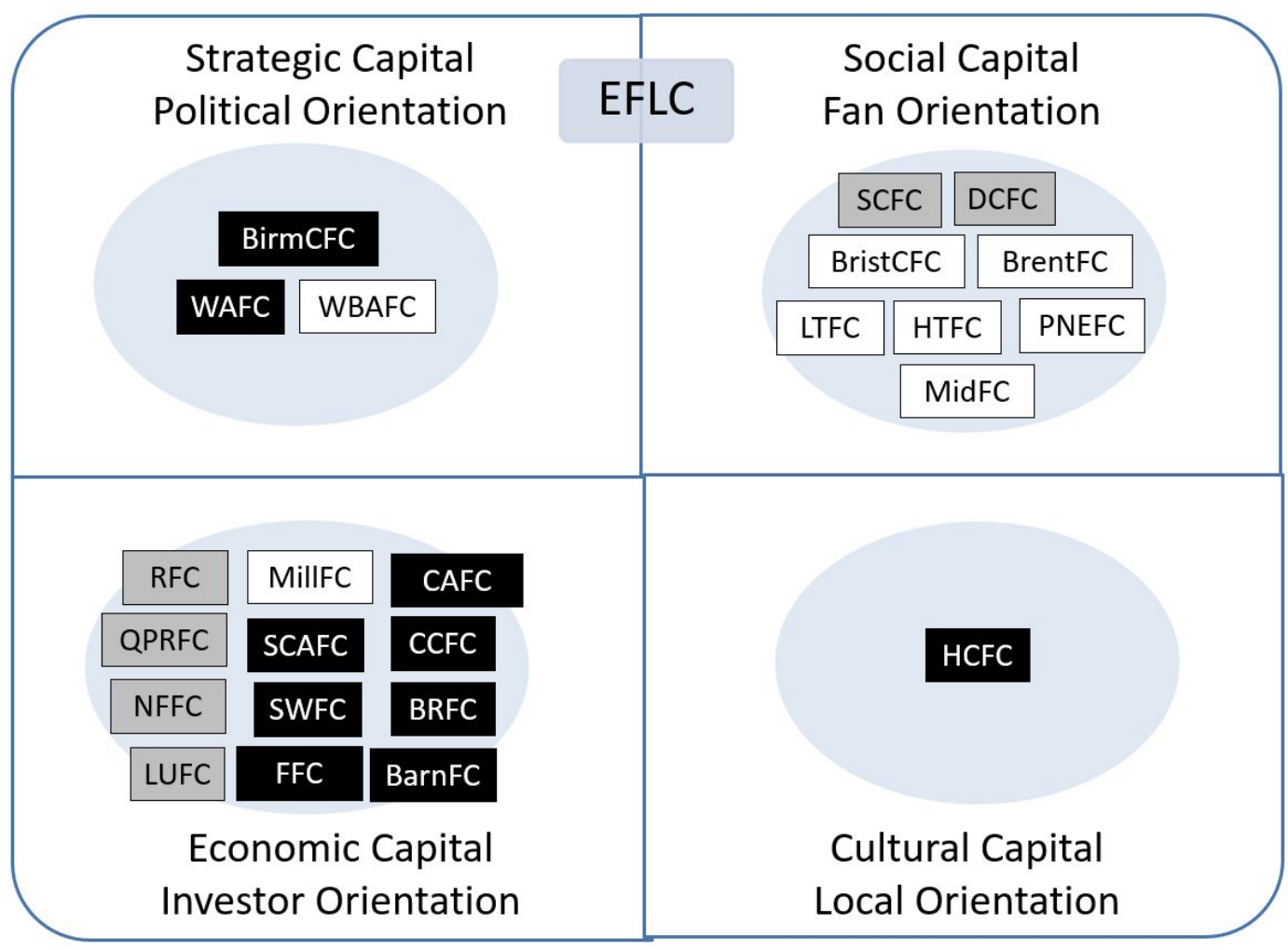

Figure 3: Orientation/Capital Mapping in the EFLC. 


\begin{tabular}{|c|c|c|c|c|c|}
\hline & EPL $(n=20)$ & $\mathrm{E}+1-$ & EFLC $(n=24)$ & $\mathbf{E + l -}$ & $\begin{array}{c}\text { Total ( } n=44 \text { ) } \\
\text { E = Equilibrium }\end{array}$ \\
\hline \multicolumn{5}{|c|}{ Strategic Capital / Political Orientation } & \\
\hline$E=+1$ & $1(5 \%)$ & +1 & $1(4 \%)$ & +1 & $2(4 \%)$ \\
\hline$E=0$ & $3(15 \%)$ & 0 & $0(0 \%)$ & 0 & $3(7 \%)$ \\
\hline$E=-1$ & $0(0 \%)$ & 0 & $2(8 \%)$ & -2 & $2(4 \%)$ \\
\hline Total & $4(20 \%)$ & +1 & $3(12 \%)$ & -1 & $E=0$ \\
\hline \multicolumn{5}{|c|}{ Economic Capital / Investor Orientation } & \\
\hline$E=+1$ & $1(10 \%)$ & +1 & $1(4 \%)$ & +1 & $2(4 \%)$ \\
\hline$E=0$ & $5(25 \%)$ & 0 & $4(16 \%)$ & 0 & $9(21 \%)$ \\
\hline$E=-1$ & $4(20 \%)$ & -4 & $7(30 \%)$ & -7 & $11(25 \%)$ \\
\hline Total & $10(50 \%)$ & -3 & $12(50 \%)$ & -6 & $E=-9$ \\
\hline $\begin{array}{l}\text { Total } \\
\text { Outsiders }\end{array}$ & $14(70 \%)$ & & $15(62 \%)$ & & $\begin{array}{c}29(66 \%) \\
E=-9\end{array}$ \\
\hline \multicolumn{5}{|c|}{ Social Capital / Fan Orientation } & \\
\hline$E=+1$ & $3(15 \%)$ & +3 & $6(24 \%)$ & +6 & $9(20 \%)$ \\
\hline$E=0$ & $0(0 \%)$ & 0 & $2(8 \%)$ & 0 & $2(4 \%)$ \\
\hline$E=-1$ & $2(10 \%)$ & -2 & $0(0 \%)$ & 0 & $2(4 \%)$ \\
\hline Total & $5(25 \%)$ & +1 & $8(32 \%)$ & +6 & $E=+7$ \\
\hline \multicolumn{5}{|c|}{ Cultural Capital / Local Orientation } & \\
\hline$E=+1$ & $0(0 \%)$ & 0 & $0(0 \%)$ & 0 & $0(0 \%)$ \\
\hline$E=0$ & $0(0 \%)$ & 0 & $0(0 \%)$ & 0 & $0(0 \%)$ \\
\hline$E=-1$ & $1(5 \%)$ & -1 & $1(4 \%)$ & -1 & $2(4 \%)$ \\
\hline Total & $1(5 \%)$ & -1 & $1(4 \%)$ & -1 & $E=-2$ \\
\hline \multirow[t]{2}{*}{$\begin{array}{l}\text { Total } \\
\text { Insiders }\end{array}$} & $6(30 \%)$ & & $9(38 \%)$ & & $\begin{array}{c}15(34 \%) \\
E=+5\end{array}$ \\
\hline & $20(100 \%)$ & & $24(100 \%)$ & & $44(100 \%)$ \\
\hline
\end{tabular}

Table 3: EPL and EFLC Orientation analysis

Tables 1,2 and 3 , \& Figures 2 and 3 about here

There are a number of observations to make between the EPL and the EFLC. Figure 2 and 3 trace the clusters of orientation of all EPL clubs and EFLC clubs in the top two English professional football leagues ${ }^{7}$.

\footnotetext{
7 We acknowledge that the mapping captures a moment in time, thus any club can transcend into disequilibrium at any moment due to the actions of the entrepreneur. This is described as the ebb and flow and the historical angle therefore captures to some extent the broader picture to accommodate rigour rather than a glimpse as ownership is naturally fluid dynamic.
} 


\subsection{Types of entrepreneurs and orientation}

All clubs were established on traditional grounds, with entrepreneurs having local and fan orientations. Pre-83 football clubs would map on Figures 2 and 3 on the right hand side (local and fan orientation - insiders), they could arguably be said to be in disequilibrium as entrepreneurs invested in clubs with little financial return, yet as King (1997) pointed out, philanthropic, social and cultural capital returns were historically the motivating characteristics for entrepreneurs - a lack of sustainability was a norm. The circumventing of Rule 34 changed the orientation, traditional entrepreneurs have in cases been displaced, as the investment required to compete has increased exponentially with the financial inflows to the industry (observed in AFCB, WFC, EFC, AVFC, CPFC, AFC, WBAFC, WAFC, RFC, SCAFC, BRFC and BFC in Appendix 1). Not only have the costs of players wages and transfer fees increased, but the facilities off field in stadium and infrastructure has transformed the game from cattle sheds like buildings to state of the art venues. Entrepreneurs have been attracted by the strategic and economic capital that has become the new orientations, as highlighted by Millward (2013).

Our first finding, shown in Tables 1,2 and 3, and Figures 2 and 3 provide us with data that identifies that 2 clubs in the two divisions (1 [less than 1\%] in each of the EPL and EFLC) are under the stewardship of insiders with Local Orientation (NUFC \& HCFC) and cultural capital. This figure is low as most traditional entrepreneurs are fans of the clubs they own, coming from the same geographical region of their team (In these two cases Mike Ashley at NUFC hails from London, but owns Newcastle United. Whilst in the EFLC, Assem Allam has lived in Hull, the club he owns since 1968, but he says he is not a football fan) - yet both are insiders as they are UK based and share the same cultural heritage.

Our second finding is in terms of Fan Orientation where there are 13 clubs (5 [25\%] in the EPL and 8 [32\%] in the EFLC) under the stewardship of entrepreneurs that are also fans of the football clubs they own (insiders). We relate fan entrepreneurs as the traditional owners of English football clubs sharing connection (social capital) and heritage with their club's other fans (see NCFC, BHAFC, BFC, THFC, WHUFC, BristCFC, DCFC, BrentFC, LTFC, HTFC, MidFC, PNEFC, SCFC). Fans entrepreneurs tend to understand other fans and respect heritage, yet, lack the wealth to compete financially with other types of entrepreneurs.

We count a combined total of $34 \%$ of clubs owned by insider entrepreneurs that share the same cultural capital and bond through social capital as their fans (15 of 44 clubs).

Our third finding is in terms of Investor Orientation where there are 22 clubs (10 [50\%] in the EPL and 12 [50\%] in the EFLC) under the stewardship of entrepreneurs that pursue economic capital and international interests (outsiders). We see from the data collected and presented in Appendix 1 that there are two sub types of investor entrepreneurs; (i) those who are global sport tycoons with a portfolio of clubs across different sports, linked to sport as an entertainment product and a global TV market (see AFC, AVFC, LFC, CPFC, MUFC, WFC, FFC, MillFC, SCAFC, ) and (ii) those who invest 
in football clubs to raise the international profile of their other business interests and seek a financial return (see AFCB, EFC, LCFC, SFC, BarnFC, BRFC, CAFC, CCFC, LUFC, NFFC, QPRFC, RFC, SWFC).

Our fourth finding is in terms of Political Orientation where there are 7 clubs ( 4 [20\% in the EPL and $3[12 \%]$ in the EFLC) under the stewardship of entrepreneurs that own football clubs to for strategic capital in raising awareness of international political interests through sport ownership (outsiders). This fourth type of entrepreneur becomes involved in English football because of the global coverage of the league, using their club as a vehicle to promote their personal wealth, or, the wealth of a nation they represent (see MCFC, SUFC, CFC, WWFC, WBAFC, BirmCFC, WAFC). These entrepreneur types have been related to literature on sports-washing, that has recently emerged (Chadwick, 2018; Kobierecki and Strozek, 2020), which suggests sport ownership is a cover-up for the image of a tarnished country, such as human rights abuse in countries such as Saudi Arabia and Qatar. Political entrepreneurs tend to have the most wealth of all entrepreneur types and can therefore appease fans with their financial investments in the club, despite their lack of understanding of the nuances of heritage and social capital and their possible relationship to unethical and unscrupulous behaviour. We see a combined total of $66 \%$ of clubs owned by international outsider entrepreneurs that have no prior connection or heritage to the football clubs they own (29 of 44 clubs). It is these orientations that we seek to draw attention to.

In drawing together these initial four findings, we conclude, as shown in Figures 2 and 3 , that there is a trend of transition to economic and strategic owners (outsiders) (supported by the data in Table 3). The EPL is categorised towards outsiders, (as seen in Table $3-\mathbf{7 0 / 3 0 \%}$ ratio), whilst the EFLC is slightly more even with a $\mathbf{6 2 / 3 8 \%}$ ratio in balance towards international outsider entrepreneurs (as seen in Table 3).

The transition indicates the leagues attract outsider international entrepreneurs. This trend has changed the identity of ownership from cultural and social orientation to a strategic and economic orientation. In 2010 in the wake of the collapse of Portsmouth Football Club (previously mentioned) there were calls for government intervention in the football industry. Of particular importance to those interested in preserving English football's heritage was the level of international outsider entrepreneurs entering the game for ulterior motives than the stewardship of the football industry (Millward, 2013; Webber, 2017). In response to the pressure for action The Department Culture Media and Sport carried out an investigation. The (DCMS, 2011) report on football governance, suggested, at that time, traditional local club owner was more commonplace than other owner types, and their inquiry into concerns raised about football ownership and governance deemed the industry as not requiring government intervention where market forces should prevail. However, as we show this balance between insider and outsider is no longer the case and we call for a new public inquiry that looks at this balance of ownership again. However, despite the trend to economic and political orientations, this alone does not evaluate or explain whether the value created in football clubs is productive or destructive. This we do through our next level of depth to our analysis.

\subsection{Productive or destructive entrepreneurship}


In our next level of analysis, we consider if the trend towards a globalised football ownership model is having an impact on the relationship with fans - causing detachment, disenchantment and protest in their individual clubs, and therefore is of something for concern to sustainable value creation. What our findings identify is a nuanced understanding of some of the complexities involved in identifying if the value created by entrepreneurs is productive or destructive, which could inform the call for a new public inquiry into the industry as requested.

Our fifth finding relates to the stability of clubs in this industry and turmoil. Just 5 clubs in the EPL and 8 clubs in the EFLC (white in Figures 2 \& 3, 13 in total [28\%]) have no history (in the previous decade) of experiencing detachment, disenchantment and protest in their individual clubs, whilst 8 clubs in the EPL and 6 clubs in the EFLC (grey in Figures 2 \& 3, 14 in total [32\%]) have a history of turmoil, leaving 7 clubs in the EPL and 10 clubs in the EFLC (black in Figures 2 \& 3, 17 in total [39\%]) that are currently in detachment, disenchantment and protest in their individual clubs. This disturbing picture therefore suggests $\mathbf{7 1 \%}$ of clubs have a recent history, if not current plight of turmoil, which is a destabilising feature of destructive value and disequilibrium in the football industry in England.

Of those clubs that have a history of turmoil links to our sixth finding. Our sixth finding is that whilst in some instances disequilibrium relates to historical protests, this is representative due to the transition of owners and longitudinal financial troubles, which highlights an issue of churn in ownership, where entrepreneurs have bought into a club for maximising economic value, only to see their investment decrease causing disequilibrium and turmoil before they exit, where a clear lack of appreciation of the industry has burnt and soured their experience, whilst causing detachment and disenchantment with the fans (denoted as colour grey in Figures 2 and 3; MCFC, WWFC, SUFC, LFC, EFC AVFC, SCFC, DCFC, RFC, QPRFC, NFFC, LUFC [details in Appendix 1]). We found $36(82 \%)$ of clubs has changed ownership (some numerously) in the past decade which is problematic for sustainable value creation in the English football industry.

Our seventh finding, as shown in Figures 1 and 2, refers back to the trend to outsider entrepreneurs in English football, outlined in the previous section. In the quadrant Investor Orientation, we see (in Table 3 ) the highest proportion of clubs (22 of the 44 [50\%] clubs) across the two divisions (an equilibrium $(E)$ rating of $E=-11$ (a negative score highlighting disequilibrium) [rebalanced to $E=-7$ with 4 clubs with a positive experience of investor orientation]). Alarmingly, there are 4 EPL clubs $(20 \%)$ and $7 \mathrm{EFLC}$ clubs $(30 \%)$ of clubs in disequilibrium in this quadrant. Within this orientation alone that amounts to 11 of 22 clubs $(\mathbf{5 0} \%)$ in disequilibrium that have investor entrepreneurs. As the detail (in Appendix 1) suggests, there are some concerning stories involving these types of entrepreneurs, such as that reported at AFC, MUFC, SCAFC, BRFC, CCFC and CAFC for the most agonizing examples detailed in Appendix 1. We note that there is a higher proportion of disequilibrium in the EFLC (Figure 2), from our research this disparity between EFLC and the EPL is in some instances due to investor entrepreneurs over-promising targets at take-over and little communication to re-address their plans for the future 2-5 years into the project (see Appendix 1, such as FFC, SWFC, RFC, QPRFC, NFFC, LUFC, BRFC), but in other instances the separation of alignment between fan and investor entrepreneur is due to social and heritage related issues (see MUFC, WHUFC, AFC, CPFC, HCFC, CCFC, BarnFC, SCAFC, CAFC, BirmCFC, WAFC) [details in Appendix 
1], such as CCFCs entrepreneur Vincent Tan, who changed the colour of the team jerseys to the annoyance of the fans, or SCAFC, who's majority shareholders sold shares to USA investors without consulting the Supporters Association that had a $21 \%$ share of the club.

However, (our eighth finding) adding to the evidence from finding seven, in the quadrant Political Orientation we see equal evidence of both dis/equilibrium $(E=0$. We see the positives as relating to the on-field success that clubs have when owners can substantially invest more cash into their clubs than other owner orientations can, however, this is balanced with clubs in turmoil, such as BirmCFC and WAFC [details in Appendix 1].

From these findings (fifth, sixth, seventh and eighth), we observe that outsiders have an equilibrium (E) rating of $E=-9$ (a negative score highlighting disequilibrium), while insiders have an equilibrium rating of $E=+5$ (a positive score highlighting equilibrium) [see Table 4]. This highlights that current and recent historical relationships between fans and types of owners across the two divisions has extensively been in disequilibrium where ownership has an outsider orientation.

Our ninth finding is to note one aspect of context, that league positioning is unrelated to dis/equilibrium, as Tables 1 and 2 show the positions in the leagues (as at June $1^{\text {st }}, 2020$, see footnote 6). Thus, entrepreneur and fan alignment is not generally success related with many clubs at the foot of each league in equilibrium. Thus, the opinions of fans tend not to be about on-field performance and is much more about the governance of the football clubs they see as theirs.

Our tenth finding is that dis/equilibrium is context specific and in some cases outsiders to the game have kept the supporters on their side (namely, 6 clubs, see Appendix 1 in relation to AVFC, AFCB, CFC, LCFC, MCFC, WBAFC), whilst some insiders have created detachment, disenchantment and protest (namely, 4 clubs, see Appendix 1 in relation to NUFC, THFC, WHUFC, HCFC). In terms of Local Orientation, we see (in Table 3) that both of the clubs (NUFC \& HCFC) in both divisions are in disequilibrium $(E=-2)$. We therefore suggest that it cannot be claimed that traditional ownership models create equilibrium and sustainable value creation per se. However, these two cases appear as anomalies, as the literature to date relates local orientation with positive relations with fans. One explanation is that these entrepreneurs behave like investor entrepreneurs, capitalising on strategic and economic capital, whilst lacking an understanding of social and cultural capital.

These ten findings show a worrying separation of alignment and negative ethical base for the football industry. Destructive entrepreneurship therefore seems to have, and has had, a significant impact on the English football industry, past and present. We therefore suggest that there is something more than simply numbers of clubs moving to outsider ownership in understanding concerns in the football industry. As we have highlighted an examination of sustainable value creation provides a deeper explanation of entrepreneurial orientation that gives greater clarity into the precarious situation this industry is in.

\section{Conclusions}

In this paper we began with the accepted assumption that 'what entrepreneurs do' is create value. For entrepreneurship theory building more generally, we would argue that this in itself is not enough. In this paper we have therefore highlighted that value creation can be precarious and destructive or 
productive and sustainable. In the case of the football industry this notion is even more complicated, partially due to the specific features of this industry, namely the main consumers of the product(s), the fans, are also involved in the production of the product. It has been argued that through their relationship with their clubs, fans have a case of moral ownership of their club, and hence are a barometer for examining equilibrium in their club in passing judgement of the value that entrepreneurs create in both the football industry and their club. With the accepted notion that entrepreneurs create value we have demonstrated that the question arises as to whether the value created is productive or destructive? In attempting to identify the value created by entrepreneurs and fans within the football industry we employed Groen's four capital framework. In applying this framework, we note that overgrazing on strategic and economic capital at the expense and exploitation of social and cultural capital exists, evidenced by detachment, disenchantment and protest in individual clubs.

What our results highlight is the complexity of understanding entrepreneurial orientation within the football industry. It is a mistake to assume broad generalisations as to the differing orientations of entrepreneurs, traditional (good) $\vee$ new (bad), insider (good) $\vee$ outsider (bad) and that context is important. Furthermore, it is important to realise that there is an ebb and flow to the balance of value in the industry, with a high churn in ownership transition in clubs, more common post 83 with the opening up of the market to entrepreneurs with the circumvention of Rule 34. However, the majority of the findings point to a threat to the sustainability of the English football industry.

At the time of writing this article there are three big football industry news stories that highlight the currency of this paper. NUFC were until recently the target of a potential takeover by Saudi Arabia's Public Investment Fund, whose chairman is Crown Prince Mohammed Bin Salman. The bid was investigated by the Premier League Authorities due to a questionable human rights record in that country and the theft of footballing rights through piracy TV (a possible example of sports washing). However, whilst the EPL authorities conducted a protracted Fit and Proper due diligence test the group pulled out. However, the vast majority of NUFC fans were in favour of the change, as it could have brought significant investment to the team and could therefore have led to a more competitive team for winning trophies, regardless of the morals of their ownership. Secondly, WAFC have recently gone into administration, a football club that changed ownership just days before it folded. WAFC shows how fragile and susceptible a club can be, especially when investors no longer see a financial return for their capital and make decisions without due consideration of the repercussions for the thousands of fans of the club but also the whole of the football industry itself. These two stories highlight both sides of this double edged sword, whilst fans wish for success and owners that can provide that, the market economy in English football is a poison challis for so many clubs with unscrupulous owners. The third story relates to the experience of watching football without fans amid the Covid 19 pandemic, the experience is somewhat devalued, the product on show without the added value of fans creating an atmosphere in the stadiums, is a vivid illustration of one way in which fans add value. 
The unique relationship between fans and clubs suggests that by acknowledging the role of fans within football clubs has greater potential for sustainable value creation in the football industry. In the words of Kornberger (2017), the values that exist outside of an organisation, can be utilized by a firm to "bring them "inside" - making them part of its "cultural toolkit". However, an appreciation of social and cultural capital is somewhat becoming a thing of the past and as English football transitions from insider entrepreneurs - those that have social and cultural attachment to the clubs they own, to outsider entrepreneurs - those that have no social and cultural attachment, yet seek to exploit the commodification of the industry. The transition therefore appears to be to kick fans out of the organisation, rather than to acknowledge their presence as part of its cultural toolkit.

There have been many campaigns by football fans for change focussing on a more accountable governance structure to ensure 'the voice' of the fans is heard and thus acknowledged in the creation of value. Within the UK this has been orchestrated by organisations such as Supporters Direct. By providing a legally binding stakeholder relationship such as the 50+ rule in the German Bundesliga (where fan representative bodies own the majority share of clubs) there is more likely to be an equilibrium solution, a balancing of the four capitals, leading to greater sustainability, yet further research is required from around the world from an entrepreneurial perspective, as Hammerschmidt, et al. (2020) also suggested.

For fans, their protest is to see their club not exploited. Club custodians need to understand and ensure that the 'capitals' enshrined within football clubs need to be in equilibrium to maintain sustainable value creation. What has become clear is that some entrepreneurs are exploiting the commodification opportunities within English football in driving forward an economic agenda at odds with the culture and heritage of English football. With our findings we also show the imbalance between insider and outsider owner types is having a detrimental impact on sustainable value creation and we call for a new public inquiry that looks at this balance of ownership and value creation. We question the current zeitgeist to outsiders, this governance turn is legitimised through a market lens, protected in business law but in the words of Keller (2007) such practices leave society with a 'low ethical base'. The counter narrative of the voice of the fans, claiming moral ownership of what they see as a community asset and a heritage worth protecting needs more attention - after all, markets do rely on consumers, don't they? 


\section{References}

Baumol, W.J. (1996), "Entrepreneurship, Productive, Unproductive and Destructive", Journal of Business Venturing, Vol. 11 No. 1, pp. 322

Bolton, B. and Thompson, J. (2004), Entrepreneurs Talent Temperament Technique, Elsevier Press, Oxford.

Brown, A. (2008), "Our club, our rules': fan communities at FC United of Manchester", Soccer \& Society, Vol. 9 No. 3, pp. 346-358.

Burns, P. (2016), Entrepreneurship and small business: start-up, growth and maturity, Fourth Edition, Palgrave Macmillan, New York.

Chadwick, S. (2018), Sport-Washing, Soft Power and Scrubbing the Stains. APPS Policy Forum, 24 August, Available at: https://www.policyforum.net/sport-washing-soft-power-andscrubbing-the-stains/. Accessed $5^{\text {th }}$ September 2020.

DCMS, (2011), Football Governance, The House of Commons. Department Culture, Media and Sport Committee. Volume III. The Stationery Office Limited.

Dimitropoulos, P., Leventis, S. and Dedoulis, E. (2016), "Managing the European football industry: UEFA's regulatory intervention and the impact on accounting quality", European Sport Management Quarterly, Vol. 16 No. 4, pp. 459-486.

Easterby-Smith, M., Thorpe, R., Jackson, P. and Jaspersen, L.J. (2018), Management and business research, Sixth Edition, Sage Publishing, Los Angeles.

Feldman, M.S. and Orlikowski, W.J. (2011), "Theorizing practice and practicing theory", Organization Science, Vol. 22 No. 5, pp. 1240-1253.

Garud, R., Gehman, J. and Giuliani, A.P. (2014), "Contextualizing entrepreneurial innovation: a narrative perspective”, Research Policy, Vol. 43 No. 7, pp. 1177-1188.

Geiger, S. and Kelly, S. (2014), "Sales-as-practice: an introduction and methodological outline”, Journal of Personal Selling \& Sales Management, Vol. 34 No. 3, pp. 223-231.

Groen, A. (2005), "Knowledge intensive entrepreneurship in networks: towards a multilevel/multi-dimensional approach", Journal of Enterprising Culture, Vol. 13 No. 1, pp. 6988.

Groen, A., Wakkee, I.A.M. and De Weerd-Nederhof, P.C. (2008), "Managing Tensions in a High-tech Start-up: An Innovation Journey in Social System perspective", International Small Business Journal, Vol. 26 No. 1, pp. 57-81.

Gross, N. and Geiger, S. (2017), "Liminality and the Entrepreneurial Firm", International Journal of Entrepreneurial Behaviour and Research, Vol. 23 No. 2, pp. 185-209. 
Hamil, S. and Walters, G. (2010), "Financial performance in English professional football: 'an inconvenient truth' ", Soccer \& Society, Vol. 11 No. 4, pp 354-372.

Hamil, S., Michie, J., Oughton, C. and Warby, S. (Eds) (2000), Football in the Digital Age: Whose Game is it Anyway? Mainstream, Edinburgh.Hammerschmidt, J., Eggers, F., Kraus, S., Jones, P. and Filser, M. (2020), "Entrepreneurial orientation in sports entrepreneurship - a mixed methods analysis of professional soccer clubs in the German-speaking countries", International Entrepreneurship and Management Journal, Vol. 16, No. 3, pp. 839-857.

Hassan, D. and Hamil, S. (2010), "Models of football governance and management in international sport", Soccer \& Society, Vol. 11 No. 4, pp 343-353.

Johannisson, B. (2011), "Towards a practice theory of entrepreneuring”, Small Business Economics, Vol. 35 No. 2, pp. 135-150.

Johannisson, B. (2014), Entrepreneurship: the practice of cunning intelligence, in Braunerhjelm, P.(Ed.), 20 Years of Entrepreneurship Research-from Small Business Dynamics to Entrepreneurial Growth and Societal Prosperity, Swedish Entrepreneurship Forum, Stockholm, pp. 109-126.

Keller, A.C. (2007), "Smith versus Friedman: Markets and ethics", Critical perspectives on Accountancy, Vol. 18 No. 2, pp. 159-188.

Kennedy, P. (2012), "The Football Industry and the Capitalist Political Economy: A Square Peg in a Round Hole?”, Critique, Vol. 40 No. 1, pp. 73-94.

Kennedy, P. (2013), “Left wing' supporter movements and the political economy of football”, Soccer \& Society, Vol. 14 No. 2, pp. 277-290.

Kennedy, P. and Kennedy, D. (2010), "Towards a Marxist Political Economy of Football Supporters", Capital \& Class, Vol. 34 No. 2, pp. 181-98.

de Vries, K. and Manfred, F.R. (1985), "The dark side of entrepreneurship”, Harvard Business Review, Vol. 85 No. 6, pp. 160-167.

King, A. (1997), "New Directors, Customers, and Fans: The Transformation of English Football in the 1990s", Sociology of Sport Journal, Vol. 14, pp. 224-240.

Kobierecki, M.M. \& Strożek, P. (2020), "Sports mega-events and shaping the international image of states: how hosting the Olympic Games and FIFA World Cups affects interest in host nations", International politics (Hague, Netherlands).

Kornberger, M. (2017), “The Values of Strategy: Valuation Practices, Rivalry and Strategic Agency”, Organization Studies, Vol. 38 No. 12, pp. 1753-1773. 
Margalit, A. (2008) "You'll Never Walk Alone: On Property, Community, and Football Fans", Theoretical Inquiries in Law, Vol. 10 No. 1, pp. 217-240.

McDougall, P.P. \& Oviatt, B.M. (2000), "International entrepreneurship: the intersection of two research paths", Academy of Management Journal, Vol. 43 No. 5, pp. 902-906.

McMullen, J.S. and Dimov, D. (2013), “Time and the entrepreneurial journey: the problems and promise of studying entrepreneurship as a process", Journal of Management Studies, Vol. 50 No. 8, pp. 1481-1512.

Michie J. (1999), New Mutualism A Golden Goal. The Cooperative Party.

Millward, P. (2013), "New football directors in the twenty-first century: profit and revenue in the English Premier League's transnational age", Leisure Studies, Vol. 32 No. 4, pp. 399-414.

Morrow, S. (2003), The People's Game? Football, Finance and Society, Palgrave, Basingstoke.

Morrow, S. (2013), "Football club financial reporting: time for a new model?" Sport, Business and Management: An International Journal, Vol. 3 No. 4, pp. 297-311.

Nash, R. (2000), “The sociology of English football”, Football Studies, Vol. 3 No. 1, pp. 4962 .

Numerato, D. (2015), "Who Says No to Modern Football? Italian Supporters, Reflexivity, and Neo-Liberalism”, Journal of Sport and Social Issues, Vol. 39, No. 2, pp. 120-138.

Pongsakornrungsilp, S. and Schroeder, J.E. (2011), "Understanding value co-creation in a coconsuming brand community”, Marketing Theory, Vol. 11 No. 3, pp. 303-324.

Ridley-Duff, R. and Bull, M. (2020), “Common Pool Resource Institutions:

The rise of internet platforms in the social solidarity economy", Business Strategy and the Environment. Forthcoming.

Rohde, M. and Breuer, C. (2017), "The market for football club investors: a review of theory and empirical evidence from professional European football", European Sport Management Quarterly, Vol. 17 No. 3, pp. 265-289.

Stake, R.E. (1995), The Art of Case Study Research, Sage, London.

Steyaert, C. (2007), "Entrepreneuring' as a conceptual attractor? A review of process theories in 20 years of entrepreneurship studies”, Entrepreneurship \& Regional Development, Vol. 19 No. 6, pp. 453-477.

Turner, M. (2014), "From local heroism to global celebrity stardom: a critical reflection of the social cultural and political changes in British football culture from the 1950 s to the formation of the premier league", Soccer \& Society, Vol. 15 No. 5, pp, 751-760. 
Warde, A. (2005), "Consumption and theories of practice", Journal of Consumer Culture, Vol. 5 No. 2, pp, 131-153.

Webber, D.M. (2017), “Playing on the break': Karl Polanyi and the double-movement 'Against Modern Football”, International Review for the Sociology of Sport, Vol. 52 No. 7, pp. 875-893.

Welter, F. (2011), "Contextualizing entrepreneurship - conceptual challenges and ways forward”, Entrepreneurship Theory and Practice, Vol. 35 No. 1, pp. 165-184.

Williams, R. (1973), The Country and the City, Oxford, UK: Oxford University Press.

Williams, R, (1977), Marxism and Literature, Oxford, UK: Oxford University Press.

Wright, M. and Zahra, S. (2011), "The other side of paradise: Examining the dark side of entrepreneurship", Entrepreneurship Research Journal, Vol. 1 No. 3, pp. 1-7.

Yin, R.K. (2003), Case study research, Thousand Oaks, CA: Sage. 
2

3

4

5

6

7

8

9

10

\begin{tabular}{|c|c|c|c|c|c|}
\hline No & $\begin{array}{l}\text { EPL Club (by League } \\
\text { Position) }\end{array}$ & $\begin{array}{l}\text { Majority Orientation } \\
\text { Cluster }\end{array}$ & $\begin{array}{l}\text { Entrepreneur } \\
\text { Type }\end{array}$ & Equilibrium/Disequilibrium & Coding \\
\hline 1 & Liverpool FC (LFC) & $\begin{array}{l}\text { Economic Capital / } \\
\text { Investor Orientation }\end{array}$ & Outsider & $\begin{array}{l}\text { Equilibrium. Yet, recent history of detachment, } \\
\text { disenchantment and protest. }\end{array}$ & $\begin{array}{l}\text { Grey } \\
\mathrm{E}=0\end{array}$ \\
\hline 2 & Manchester City FC (MCFC) & $\begin{array}{l}\text { Strategic Capital / } \\
\text { Political Orientation }\end{array}$ & Outsider & $\begin{array}{l}\text { Equilibrium. Yet, recent history of detachment, } \\
\text { disenchantment and protest. }\end{array}$ & $\begin{array}{l}\text { Grey } \\
E=0\end{array}$ \\
\hline 3 & $\begin{array}{l}\text { Manchester United FC } \\
\text { (MUFC) }\end{array}$ & $\begin{array}{l}\text { Economic Capital / } \\
\text { Investor Orientation }\end{array}$ & Outsider & $\begin{array}{l}\text { Disequilibrium. Detachment, disenchantment and } \\
\text { protest. }\end{array}$ & $\begin{array}{l}\text { Black } \\
\mathrm{E}=-1\end{array}$ \\
\hline 4 & Chelsea FC (CFC) & $\begin{array}{l}\text { Strategic Capital / } \\
\text { Political Orientation }\end{array}$ & Outsider & $\begin{array}{l}\text { Equilibrium. No reports of detachment, } \\
\text { disenchantment or protest. }\end{array}$ & $\begin{array}{l}\text { White } \\
\mathrm{E}=+1\end{array}$ \\
\hline 5 & Leicester City FC (LCFC) & $\begin{array}{l}\text { Economic Capital / } \\
\text { Investor Orientation }\end{array}$ & Outsider & $\begin{array}{l}\text { Equilibrium. Yet, recent history of detachment, } \\
\text { disenchantment and protest. }\end{array}$ & $\begin{array}{l}\text { Grey } \\
\mathrm{E}=0\end{array}$ \\
\hline 6 & $\begin{array}{l}\text { Tottenham Hotspur FC } \\
\text { (THFC) }\end{array}$ & $\begin{array}{l}\text { Social Capital / Fan } \\
\text { Orientation }\end{array}$ & Insider & $\begin{array}{l}\text { Disequilibrium. Detachment, disenchantment and } \\
\text { protest. }\end{array}$ & $\begin{array}{l}\text { Black } \\
\mathrm{E}=-1\end{array}$ \\
\hline 7 & $\begin{array}{l}\text { Wolverhampton Wanderers } \\
\text { FC (WWFC) }\end{array}$ & $\begin{array}{l}\text { Strategic Capital / } \\
\text { Political Orientation }\end{array}$ & Outsider & $\begin{array}{l}\text { Equilibrium. Yet, recent history of detachment, } \\
\text { disenchantment and protest. }\end{array}$ & $\begin{array}{l}\text { Grey } \\
E=0\end{array}$ \\
\hline 8 & Arsenal FC (AFC) & $\begin{array}{l}\text { Economic Capital / } \\
\text { Investor Orientation }\end{array}$ & Outsider & $\begin{array}{l}\text { Disequilibrium. Detachment, disenchantment and } \\
\text { protest. }\end{array}$ & $\begin{array}{l}\text { Black } \\
\mathrm{E}=-1\end{array}$ \\
\hline 9 & Sheffield United FC (SUFC) & $\begin{array}{l}\text { Strategic Capital / } \\
\text { Political Orientation }\end{array}$ & Outsider & $\begin{array}{l}\text { Equilibrium. Yet, recent history of detachment, } \\
\text { disenchantment and protest. }\end{array}$ & $\begin{array}{l}\text { Grey } \\
\mathrm{E}=0\end{array}$ \\
\hline 10 & Burnley FC (BFC) & $\begin{array}{l}\text { Social Capital / Fan } \\
\text { Orientation }\end{array}$ & Insider & $\begin{array}{l}\text { Equilibrium. No reports of detachment, } \\
\text { disenchantment or protest. }\end{array}$ & $\begin{array}{l}\text { White } \\
E=+1\end{array}$ \\
\hline 11 & Southampton FC (SFC) & $\begin{array}{l}\text { Economic Capital / } \\
\text { Investor Orientation }\end{array}$ & Outsider & $\begin{array}{l}\text { Disequilibrium. Detachment, disenchantment and } \\
\text { protest. }\end{array}$ & $\begin{array}{l}\text { Black } \\
E=-1\end{array}$ \\
\hline 12 & Everton FC (EFC) & $\begin{array}{l}\text { Economic Capital / } \\
\text { Investor Orientation }\end{array}$ & Outsider & $\begin{array}{l}\text { Equilibrium. Yet, recent history of detachment, } \\
\text { disenchantment and protest. }\end{array}$ & $\begin{array}{l}\text { Grey } \\
E=0\end{array}$ \\
\hline 13 & $\begin{array}{l}\text { Newcastle United FC } \\
\text { (NUFC) }\end{array}$ & $\begin{array}{l}\text { Cultural Capital / } \\
\text { Local Orientation }\end{array}$ & Insider & $\begin{array}{l}\text { Disequilibrium. Detachment, disenchantment and } \\
\text { protest. }\end{array}$ & $\begin{array}{l}\text { Black } \\
E=-1\end{array}$ \\
\hline 14 & Crystal Palace FC (CPFC) & $\begin{array}{l}\text { Economic Capital / } \\
\text { Investor Orientation }\end{array}$ & Outsider & $\begin{array}{l}\text { Disequilibrium. Detachment, disenchantment and } \\
\text { protest. }\end{array}$ & $\begin{array}{l}\text { Black } \\
\mathrm{E}=-1\end{array}$ \\
\hline 15 & $\begin{array}{l}\text { Brighton \& Hove Albion FC } \\
\text { (B\&HAFC) }\end{array}$ & $\begin{array}{l}\text { Social Capital / Fan } \\
\text { Orientation }\end{array}$ & Insider & $\begin{array}{l}\text { Equilibrium. No reports of detachment, } \\
\text { disenchantment or protest. }\end{array}$ & $\begin{array}{l}\text { White } \\
E=+1\end{array}$ \\
\hline 16 & $\begin{array}{l}\text { West Ham United FC } \\
\text { (WHUFC) }\end{array}$ & $\begin{array}{l}\text { Social Capital / Fan } \\
\text { Orientation }\end{array}$ & Insider & $\begin{array}{l}\text { Disequilibrium. Detachment, disenchantment and } \\
\text { protest. }\end{array}$ & $\begin{array}{l}\text { Black } \\
\mathrm{E}=-1\end{array}$ \\
\hline 17 & Aston Villa FC (AVFC) & $\begin{array}{l}\text { Economic Capital / } \\
\text { Investor Orientation }\end{array}$ & Outsider & $\begin{array}{l}\text { Equilibrium. Yet, recent history of detachment, } \\
\text { disenchantment and protest. }\end{array}$ & $\begin{array}{l}\text { Grey } \\
\mathrm{E}=0\end{array}$ \\
\hline 18 & AFC Bournemouth (AFCB) & $\begin{array}{l}\text { Economic Capital / } \\
\text { Investor Orientation }\end{array}$ & Outsider & $\begin{array}{l}\text { Equilibrium. No reports of detachment, } \\
\text { disenchantment or protest. }\end{array}$ & $\begin{array}{l}\text { White } \\
\mathrm{E}=+1\end{array}$ \\
\hline 19 & Watford FC (WFC) & $\begin{array}{l}\text { Economic Capital / } \\
\text { Investor Orientation }\end{array}$ & Outsider & $\begin{array}{l}\text { Equilibrium. Yet, recent history of detachment, } \\
\text { disenchantment and protest. }\end{array}$ & $\begin{array}{l}\text { Grey } \\
E=0\end{array}$ \\
\hline 20 & Norwich City FC (NCFC) & $\begin{array}{l}\text { Social Capital / Fan } \\
\text { Orientation }\end{array}$ & Insider & $\begin{array}{l}\text { Equilibrium. No reports of detachment, } \\
\text { disenchantment or protest. }\end{array}$ & $\begin{array}{l}\text { White } \\
E=+1\end{array}$ \\
\hline
\end{tabular}

Table 1: Evaluating Equilibrium/Disequilibrium in the EPL in final league position order. 


\begin{tabular}{|c|c|c|c|c|c|}
\hline No & $\begin{array}{l}\text { EFLC Club (by League } \\
\text { Position) }\end{array}$ & $\begin{array}{l}\text { Majority Orientation } \\
\text { Cluster }\end{array}$ & $\begin{array}{l}\text { Entrepreneur } \\
\text { Type }\end{array}$ & Equilibrium/Disequilibrium & Coding \\
\hline 1 & Leeds United FC (LUFC) & $\begin{array}{l}\text { Economic Capital / } \\
\text { Investor Orientation }\end{array}$ & Outsider & $\begin{array}{l}\text { Equilibrium. Yet, recent history of detachment, } \\
\text { disenchantment and protest. }\end{array}$ & $\begin{array}{l}\text { Grey } \\
\mathrm{E}=0\end{array}$ \\
\hline 2 & $\begin{array}{l}\text { West Bromwich Albion FC } \\
\text { (WBAFC) }\end{array}$ & $\begin{array}{l}\text { Strategic Capital / } \\
\text { Political Orientation }\end{array}$ & Outsider & $\begin{array}{l}\text { Equilibrium. No reports of detachment, } \\
\text { disenchantment or protest. }\end{array}$ & $\begin{array}{l}\text { White } \\
E=+1\end{array}$ \\
\hline 3 & Brentford FC (BrentFC) & $\begin{array}{l}\text { Cultural Capital / Fan } \\
\text { Orientation }\end{array}$ & Insider & $\begin{array}{l}\text { Equilibrium. No reports of detachment, } \\
\text { disenchantment or protest. }\end{array}$ & $\begin{array}{l}\text { White } \\
E=+1\end{array}$ \\
\hline 4 & Fulham FC (FFC) & $\begin{array}{l}\text { Economic Capital / } \\
\text { Investor Orientation }\end{array}$ & Outsider & $\begin{array}{l}\text { Disequilibrium. Detachment, disenchantment and } \\
\text { protest. }\end{array}$ & $\begin{array}{l}\text { Black } \\
\mathrm{E}=-1\end{array}$ \\
\hline 5 & Cardiff City FC (CCFC) & $\begin{array}{l}\text { Economic Capital / } \\
\text { Investor Orientation }\end{array}$ & Outsider & $\begin{array}{l}\text { Disequilibrium. Detachment, disenchantment and } \\
\text { protest. }\end{array}$ & $\begin{array}{l}\text { Black } \\
\mathrm{E}=-1\end{array}$ \\
\hline 6 & Swansea City AFC (SCAFC) & $\begin{array}{l}\text { Economic Capital / } \\
\text { Investor Orientation }\end{array}$ & Outsider & $\begin{array}{l}\text { Disequilibrium. Detachment, disenchantment and } \\
\text { protest. }\end{array}$ & $\begin{array}{l}\text { Black } \\
\mathrm{E}=-1\end{array}$ \\
\hline 7 & $\begin{array}{l}\text { Nottingham Forest FC } \\
\text { (NFFC) }\end{array}$ & $\begin{array}{l}\text { Economic Capital / } \\
\text { Investor Orientation }\end{array}$ & Outsider & $\begin{array}{l}\text { Equilibrium. Yet, recent history of detachment, } \\
\text { disenchantment and protest. }\end{array}$ & $\begin{array}{l}\text { Grey } \\
E=0\end{array}$ \\
\hline 8 & Millwall FC (MillFC) & $\begin{array}{l}\text { Economic Capital / } \\
\text { Investor Orientation }\end{array}$ & Outsider & $\begin{array}{l}\text { Equilibrium. No reports of detachment, } \\
\text { disenchantment or protest. }\end{array}$ & $\begin{array}{l}\text { White } \\
E=+1\end{array}$ \\
\hline 9 & $\begin{array}{l}\text { Preston North End FC } \\
\text { (PNEFC) }\end{array}$ & $\begin{array}{l}\text { Cultural Capital / Fan } \\
\text { Orientation }\end{array}$ & Insider & $\begin{array}{l}\text { Equilibrium. No reports of detachment, } \\
\text { disenchantment or protest. }\end{array}$ & $\begin{array}{l}\text { White } \\
E=+1\end{array}$ \\
\hline 10 & Derby County FC (DCFC) & $\begin{array}{l}\text { Cultural Capital / Fan } \\
\text { Orientation }\end{array}$ & Insider & $\begin{array}{l}\text { Equilibrium. Yet, recent history of detachment, } \\
\text { disenchantment and protest. }\end{array}$ & $\begin{array}{l}\text { Grey } \\
\mathrm{E}=0\end{array}$ \\
\hline 11 & Blackburn Rovers (BRFC) & $\begin{array}{l}\text { Economic Capital / } \\
\text { Investor Orientation }\end{array}$ & Outsider & $\begin{array}{l}\text { Disequilibrium. Detachment, disenchantment and } \\
\text { protest. }\end{array}$ & $\begin{array}{l}\text { Black } \\
E=-1\end{array}$ \\
\hline 12 & Bristol City FC (BristCFC) & $\begin{array}{l}\text { Cultural Capital / Fan } \\
\text { Orientation }\end{array}$ & Insider & $\begin{array}{l}\text { Equilibrium. No reports of detachment, } \\
\text { disenchantment or protest. }\end{array}$ & $\begin{array}{l}\text { White } \\
E=+1\end{array}$ \\
\hline 13 & $\begin{array}{l}\text { Queens Park Rangers FC } \\
\text { (QPRFC) }\end{array}$ & $\begin{array}{l}\text { Economic Capital / } \\
\text { Investor Orientation }\end{array}$ & Outsider & $\begin{array}{l}\text { Equilibrium. Yet, recent history of detachment, } \\
\text { disenchantment and protest. }\end{array}$ & $\begin{array}{l}\text { Grey } \\
E=0\end{array}$ \\
\hline 14 & Reading FC (RFC) & $\begin{array}{l}\text { Economic Capital / } \\
\text { Investor Orientation }\end{array}$ & Outsider & $\begin{array}{l}\text { Equilibrium. Yet, recent history of detachment, } \\
\text { disenchantment and protest. }\end{array}$ & $\begin{array}{l}\text { Grey } \\
\mathrm{E}=0\end{array}$ \\
\hline 15 & Stoke City FC (SCFC) & $\begin{array}{l}\text { Cultural Capital / Fan } \\
\text { Orientation }\end{array}$ & Insider & $\begin{array}{l}\text { Equilibrium. Yet, recent history of detachment, } \\
\text { disenchantment and protest. }\end{array}$ & $\begin{array}{l}\text { Grey } \\
E=0\end{array}$ \\
\hline 16 & $\begin{array}{l}\text { Sheffield Wednesday FC } \\
\text { (SWFC) }\end{array}$ & $\begin{array}{l}\text { Economic Capital / } \\
\text { Investor Orientation }\end{array}$ & Outsider & $\begin{array}{l}\text { Disequilibrium. Detachment, disenchantment and } \\
\text { protest. }\end{array}$ & $\begin{array}{l}\text { Black } \\
E=-1\end{array}$ \\
\hline 17 & Middlesbrough FC (MidFC) & $\begin{array}{l}\text { Cultural Capital / Fan } \\
\text { Orientation }\end{array}$ & Insider & $\begin{array}{l}\text { Equilibrium. No reports of detachment, } \\
\text { disenchantment or protest. }\end{array}$ & $\begin{array}{l}\text { White } \\
E=+1\end{array}$ \\
\hline 18 & $\begin{array}{l}\text { Huddersfield Town FC } \\
\text { (HTFC) }\end{array}$ & $\begin{array}{l}\text { Cultural Capital / Fan } \\
\text { Orientation }\end{array}$ & Insider & $\begin{array}{l}\text { Equilibrium. No reports of detachment, } \\
\text { disenchantment or protest. }\end{array}$ & $\begin{array}{l}\text { White } \\
E=+1\end{array}$ \\
\hline 19 & Luton Town FC (LTFC) & $\begin{array}{l}\text { Cultural Capital / Fan } \\
\text { Orientation }\end{array}$ & Insider & $\begin{array}{l}\text { Equilibrium. No reports of detachment, } \\
\text { disenchantment or protest. }\end{array}$ & $\begin{array}{l}\text { White } \\
E=+1\end{array}$ \\
\hline 20 & $\begin{array}{l}\text { Birmingham City FC } \\
\text { (BirmCFC) }\end{array}$ & $\begin{array}{l}\text { Strategic Capital / } \\
\text { Political Orientation }\end{array}$ & Outsider & $\begin{array}{l}\text { Disequilibrium. Detachment, disenchantment and } \\
\text { protest. }\end{array}$ & $\begin{array}{l}\text { Black } \\
E=-1\end{array}$ \\
\hline 21 & Barnsley (BarnFC) & $\begin{array}{l}\text { Economic Capital / } \\
\text { Investor Orientation }\end{array}$ & Outsider & $\begin{array}{l}\text { Disequilibrium. Detachment, disenchantment and } \\
\text { protest. }\end{array}$ & $\begin{array}{l}\text { Black } \\
\mathrm{E}=-1\end{array}$ \\
\hline 22 & Charlton Athletic (CAFC) & $\begin{array}{l}\text { Economic Capital / } \\
\text { Investor Orientation }\end{array}$ & Outsider & $\begin{array}{l}\text { Disequilibrium. Detachment, disenchantment and } \\
\text { protest. }\end{array}$ & $\begin{array}{l}\text { Black } \\
\mathrm{E}=-1\end{array}$ \\
\hline 23 & Wigan Athletic FC (WAFC) & $\begin{array}{l}\text { Strategic Capital / } \\
\text { Political Orientation }\end{array}$ & Outsider & $\begin{array}{l}\text { Disequilibrium. Detachment, disenchantment and } \\
\text { protest. }\end{array}$ & $\begin{array}{l}\text { Black } \\
E=-1\end{array}$ \\
\hline 24 & Hull City (HCFC) & $\begin{array}{l}\text { Cultural Capital / } \\
\text { Local Orientation }\end{array}$ & Insider & $\begin{array}{l}\text { Disequilibrium. Detachment, disenchantment and } \\
\text { protest. }\end{array}$ & $\begin{array}{l}\text { Black } \\
E=-1\end{array}$ \\
\hline
\end{tabular}

Table 2: Evaluating Equilibrium/Disequilibrium in the ELFC in final league position order. 


\begin{tabular}{|c|c|c|c|c|c|}
\hline & EPL $(n=20)$ & $E+/-$ & EFLC (n=24) & $E+/-$ & $\begin{array}{c}\text { Total }(n=44) \\
\text { E = Equilibrium }\end{array}$ \\
\hline \multicolumn{5}{|c|}{ Strategic Capital / Political Orientation } & \\
\hline$E=+1$ & $1(5 \%)$ & +1 & $1(4 \%)$ & +1 & $2(4 \%)$ \\
\hline$E=0$ & $3(15 \%)$ & 0 & $0(0 \%)$ & 0 & $3(7 \%)$ \\
\hline$E=-1$ & $0(0 \%)$ & 0 & $2(8 \%)$ & -2 & $2(4 \%)$ \\
\hline Total & $4(20 \%)$ & +1 & $3(12 \%)$ & -1 & $E=0$ \\
\hline \multicolumn{5}{|c|}{ Economic Capital / Investor Orientation } & \\
\hline$E=+1$ & $1(10 \%)$ & +1 & $1(4 \%)$ & +1 & $2(4 \%)$ \\
\hline$E=0$ & $5(25 \%)$ & 0 & $4(16 \%)$ & 0 & $9(21 \%)$ \\
\hline$E=-1$ & $4(20 \%)$ & -4 & $7(30 \%)$ & -7 & $11(25 \%)$ \\
\hline Total & $10(50 \%)$ & -3 & $12(50 \%)$ & -6 & $E=-9$ \\
\hline $\begin{array}{l}\text { Total } \\
\text { Outsiders }\end{array}$ & $14(70 \%)$ & & $15(62 \%)$ & & $\begin{array}{c}29(66 \%) \\
E=-9\end{array}$ \\
\hline \multicolumn{5}{|c|}{ Social Capital / Fan Orientation } & \\
\hline$E=+1$ & $3(15 \%)$ & +3 & $6(24 \%)$ & +6 & $9(20 \%)$ \\
\hline$E=0$ & $0(0 \%)$ & 0 & $2(8 \%)$ & 0 & $2(4 \%)$ \\
\hline$E=-1$ & $2(10 \%)$ & -2 & $0(0 \%)$ & 0 & $2(4 \%)$ \\
\hline Total & $5(25 \%)$ & +1 & $8(32 \%)$ & +6 & $E=+7$ \\
\hline \multicolumn{5}{|c|}{ Cultural Capital / Local Orientation } & \\
\hline$E=+1$ & $0(0 \%)$ & 0 & $0(0 \%)$ & 0 & $0(0 \%)$ \\
\hline$E=0$ & $0(0 \%)$ & 0 & $0(0 \%)$ & 0 & $0(0 \%)$ \\
\hline$E=-1$ & $1(5 \%)$ & -1 & $1(4 \%)$ & -1 & $2(4 \%)$ \\
\hline Total & $1(5 \%)$ & -1 & $1(4 \%)$ & -1 & $E=-2$ \\
\hline \multirow[t]{2}{*}{$\begin{array}{l}\text { Total } \\
\text { Insiders }\end{array}$} & $6(30 \%)$ & & $9(38 \%)$ & & $\begin{array}{c}15(34 \%) \\
E=+5\end{array}$ \\
\hline & $20(100 \%)$ & & $24(100 \%)$ & & $44(100 \%)$ \\
\hline
\end{tabular}

Table 3: EPL and EFLC Orientation analysis 


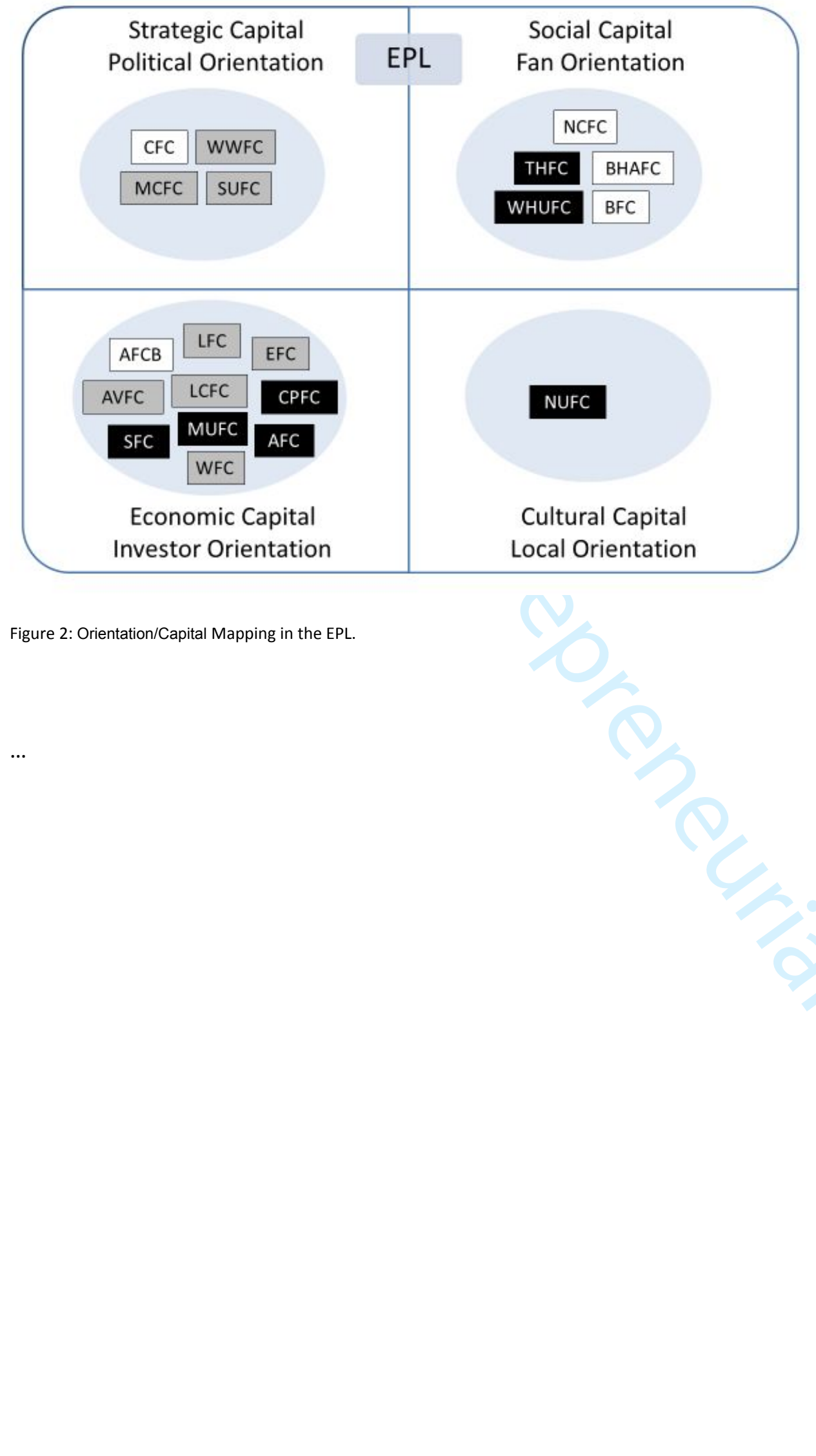




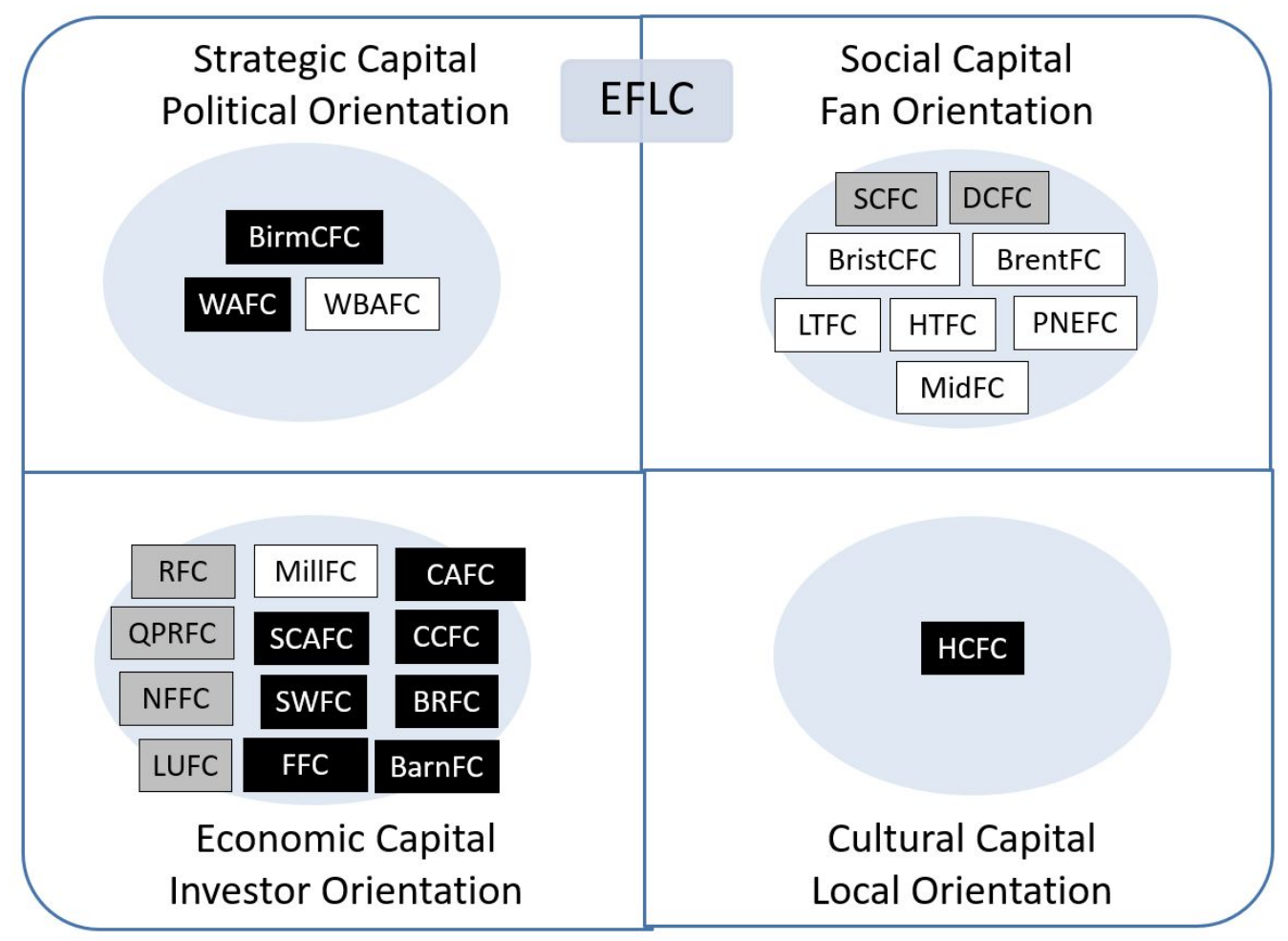

Figure 3: Orientation/Capital Mapping in the EFLC. 
Appendix $1 \ldots$

\begin{tabular}{|c|c|c|c|}
\hline \multicolumn{4}{|c|}{ English Premier League (Season 2019/20) } \\
\hline Football Club & Controlling Party/ Owner/s & Stake & Origins \\
\hline $\begin{array}{l}\text { Arsenal Football Club } 1 \\
\text { (AFC) }\end{array}$ & Stanley Kroenke & $100 \%$ & USA \\
\hline
\end{tabular}

There is current turmoil at Arsenal. Fans are in protest of the club stewardship and the current owner ${ }^{2}$, causing detachment and disenchantment, instigated by the compulsory purchase of minority fan shares in the club when he took full control. The \#Kroenkeout protest campaign has 26,723 posts on Instagram ${ }^{3}$

Disequilibrium. Detachment, disenchantment and protest.

\begin{tabular}{l|l|l|l}
\hline Aston Villa Football Club (AVFC) & Nassef Sawiris & $50 \%$ & Egypt \\
\hline & Wes Edens & $50 \%$ & USA
\end{tabular}

Sawiris and Edens bought into Villa in 2018 after two separate periods of turmoil under previous owner Xia (the club came close to administration ${ }^{5}$ ) and Lerner 6 . In 2019 Sawiris and Edens took full control ${ }^{7}$. No protests noted under the current regime. Equilibrium. Yet, recent history of detachment, disenchantment and protest.

Association Football Club

Bournemouth

(AFCB)

Maxim Demin 8

$100 \%$

Russia

When Demin took control in 2011 they were in the third tier of the English football pyramid. Their investments secured two promotions in three seasons, with the Club 2015/16 in the EPL for the first time in their history. The Russian entrepreneur's motivation would appear to be the financial rewards of competing in the EPL, which they have been successful at achieving. The fans appear to be in harmony with the owners (coded white in Figure 3). No protests recorded. Equilibrium. No reports of detachment, disenchantment or protest.

\begin{tabular}{|c|c|c|}
\hline Brighton \& Hove Albion Football & Tony Bloom & $76 \%$ \\
\hline Club (BHAFC) ${ }^{9}$ & Individual shareholders & $24 \%$ \\
\hline
\end{tabular}

BHAFC fan Bloom became majority shareholder in 2009, making a new ground in Brighton his priority ${ }^{10}$. The Amex Stadium opened August 2015. No protests recorded. Equilibrium. No reports of detachment, disenchantment or protest.

Burnley Football Club ${ }^{11}$

(BFC)

\begin{tabular}{|l|l|l|}
\hline Mike Garlick & $47.33 \%$ & UK \\
\hline John Banaszkiewicz & $27.55 \%$ & UK \\
\hline Individual shareholders & $25.12 \%$ & \\
\hline
\end{tabular}

BFC have fan owners in Garlick and Banaszkiewcz, the latter stepping down as co-chair in July 2015. The Club is run on a sustainability model, with slow growth that has brought rewards through promotion to the EPL in 2009, after a 33 year absence. Much of the development of the Club in this period was down to former Chair (and fan owner from 1999) Barry Kilby ${ }^{12}$. No protests recorded. Equilibrium. No reports of detachment, disenchantment or protest. 


\section{Chelsea Football Club ${ }^{13}$}

(CFC)

\section{Roman Abramovich}

$100 \%$

Russia

Under the ownership of entrepreneur Abramovich Chelsea have sustained a period of success ${ }^{14}$. Protests against some of the managerial appointments noted over the period of reign but no ownership tensions. Equilibrium. No reports of detachment, disenchantment or protest.

\section{Crystal Palace Football Club ${ }^{15}$ (CPFC)}

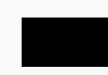

\begin{tabular}{|c|c|c|}
\hline Steve Parish & $18 \%$ & UK \\
\hline Joshua Harris & $18 \%$ & USA \\
\hline David Blitzer & $18 \%$ & USA \\
\hline CPFC2010 & $46 \%$ & UK \\
\hline
\end{tabular}

CPFC were equally owned by four UK fan owners, until in late 2015 US sport industry investors Harris and Blitzer, who also own New Jersey Devils of the NHL and Philadelphia 76ers of the NBA ${ }^{16}$ acquired a stake. The Club still have a minority of individual fan shareholders through CPFC2010. Continued calls for the Board to invest in the team have been around for a few years, with fan disenchantment recorded on a number of website posts that continue this season ${ }^{17}$ Disequilibrium. Detachment, disenchantment and protest.

\begin{tabular}{|c|c|c|c|}
\hline \multirow{3}{*}{$\begin{array}{l}\text { Everton Football Club }{ }^{18} \\
(E F C)\end{array}$} & Farhad Moshiri & $77.23 \%$ & Iran \\
\hline & Bill Kenwright & $5 \%$ & UK \\
\hline & Individual Shareholders & $17.77 \%$ & UK \\
\hline
\end{tabular}

Recent acquisition of the majority shareholding in EFC by entrepreneur Moshiri, an ex-Arsenal investor was completed in February 2016. ${ }^{19}$ Protests have been rife since in 2011 at the running of the club under the fan ownership of Kenwright, where fans felt they wanted new owners to invest in the club ${ }^{20}$.

Equilibrium. Yet, recent history of detachment, disenchantment and protest.

Leicester City Football Club21

(LCFC)

\section{The Srivaddhanaprabha family $\quad 100 \%$}

Thailand

A recent Premier League title and a stable five years of growth under the stewardship of the

Srivaddhanaprabha's have not gone unappreciated by the clubs fans ${ }^{22}$. Despite excessive branding of the Srivaddhanaprabha's company King Power, no protests recorded. Equilibrium. No reports of detachment, disenchantment or protest.

\begin{tabular}{l|l|l|l}
$\begin{array}{l}\text { Liverpool Football Club } \\
\text { (LFC) }\end{array}$ & $\begin{array}{l}\text { John Henry (Fenway Sports } \\
\text { Group) }\end{array}$ & $100 \%^{23}$ & USA
\end{tabular}

After the turmoil of the club under previous owners Hicks and Gillett, who saddled the club with debt ${ }^{24}$,

Liverpool fans hold Henry in slightly higher regard, although questioning their managerial decision making prior to the appointment of Jurgen Klopp and excessive player investment that has not always been seen as shroud purchases ${ }^{25}$.

Equilibrium. Yet, recent history of detachment, disenchantment and protest.

${ }^{13} \mathrm{http} / / /$ www.chelseafc.com/the-club/about-chelsea-football-club/club-personnel.htm/

${ }_{14} \mathrm{http}: / /$ www.independent.co.uk/sport/football/premier-league/roman-abramovich-reaches-700-games-as-chelsea-owner-but-how-does-his-reign-stack-up-against-the-rest-10171465.htm

${ }_{15}^{14}$ http://www.independent.co.uk/sport/

${ }_{16}^{15}$ http://www.cpfc.co.uk/club/whoswho/

${ }_{17} \mathrm{https://www.footballtransfertavern.com/premier-league/crystal-palace/crystal-palace-fans-annoyed-by-clubs-post-about-record-points-haul/}$

${ }_{18}^{18}$ https://www.theguardian.com/football/2016/mar/02/bill-kenwright-everton-farhad-moshiri-takeover

${ }_{19} \mathrm{https}: / /$ www.evertonfc.com/club/shareholders/list-of-shareholders

${ }^{20} \mathrm{https://www.theguardian.com/football/blog/2011/sep/09/everton-fans-new-owner}$

${ }^{21} \mathrm{http} / / /$ www.leicestermercury.co.uk/Leicester-City-FC-reveal-owners-120m-club/story-20766994-detail/story.html

${ }^{22}$ http://leicestercitynews.co.uk/?E=61

${ }^{23} \mathrm{http://www.liverpoolfc.com/corporate/directors}$

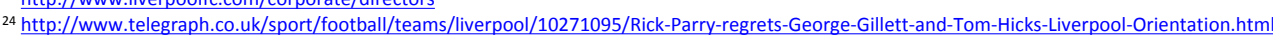

25 http://www.liverpoolecho.co.uk/sport/football/football-news/blood-red-klopps-liverpool-fc-10234106 


\section{Manchester City Football Club 26} (MCFC)

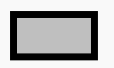

\begin{tabular}{|l|l|l|}
\hline $\begin{array}{l}\text { Sheikh Mansour Bin Zayed Al } \\
\text { Nahyan }\end{array}$ & $85 \%$ & $\begin{array}{l}\text { United Arab } \\
\text { Emirates }\end{array}$ \\
\hline Ruigang Lij & & China \\
\hline
\end{tabular}

After a negative experience with previous (Investor Orientation) owner Thai Prime Minister Thaksin Shinawarta, where his assets were frozen amid corruption ${ }^{28}$, the sale of the Club to the current (Political Orientation) owners in 2008 was followed by several high value transfers of players and by 2012 MCFC had spent $£ 930 \mathrm{~m}$ in the period $^{29}$ and had won the EPL four times, the FA Cup once and the Football League Cup five times. With the Gulf states increasingly looking at life beyond oil and gas the purchase of City appears to be a part of a long term strategic investment by the Gulf State into Western cultural and sporting activities ${ }^{30}$. Interestingly, City recently removed the words 'football club' from their club badge. However, the fans appear aligned to the entrepreneur's objectives, with no detachment, disenchantment or protest evident. Equilibrium. Yet, recent history of detachment, disenchantment and protest.

Manchester United Football Club (MUFC)

The takeover of Manchester United (MUFC) by entrepreneur Malcolm Glazer was highly contentious. After gaining an initial stake in the club in 2003, Glazer acquired additional shares in 2004 and made known to the Board he wanted full control of the Club. The deal was labelled as 'damaging' by then Chief Executive David Gill $^{32}$ because the deal involved leveraged buy-out - saddling the Club with $£ 500 \mathrm{~m}$ of debt ${ }^{33}$. Many of the Club's fans were also against the deal, with several highly publicised demonstrations ${ }^{34}$. Fans group MUST (Manchester United Supporters Trust), claimed, "Not investing a single penny might be considered an 'ownership crime' by fans at most clubs but far worse than that they (the Glazers) have actually extracted colossal sums from Manchester United... When all interest and charges on their leveraged buyout is added up, plus money they've paid themselves, plus related debt still on the club, they've taken more than $£ 1$ billion and it's still rising.... No owner in the history of football in any country, ever, has taken so much money from a club". 35 The motivation would appear to be the financial rewards of competing in the EPL (whilst possibly servicing other interests, as Glazer's other assets were under-performing). The Glazer sale led to some fans (around 2-3,000) starting their own fan-owned Club in protest (FC United of Manchester), nicknamed The Rebels. Disequilibrium. Detachment, disenchantment and protest.

Newcastle United Football Club ${ }^{36}$

(NUFC)

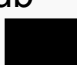

Mike Ashley

$100 \%$

UK

The thorny relationship between Ashley and fans is well publicised (with 14,000 followers of \#AshleyOut.com on Twitter), with protests and numerous campaigns to oust him ${ }^{37}$. Reports claim fans are disenchanted with his lack of ambition for the Club beyond Premier League survival ${ }^{38}$. Fans are also against what is described as tacky branding, with Ashley's company Sports Direct an ever present logo positioned around the football club's home stadium, whose name was changed in 2011 from St. James' Park to Sports Direct Arena, before outcry and detracting the change ${ }^{39}$. Disequilibrium. Detachment, disenchantment and protest.

${ }^{26} \mathrm{http}: / / \mathrm{www} \cdot \mathrm{mcfc} . \mathrm{co} . \mathrm{uk} /$ The-Club/Corporate-Info

${ }^{27}$ http://www.bbc.co.uk/news/business-34972478

${ }^{28}$ http://news.bbc.co.uk/sport1/hi/football/teams/m/man_city/7545428.stm

${ }^{29} \mathrm{http} / / /$ www.telegraph.co.uk/sport/football/teams/manchester-city/9255702/Manchester-Citys-930-million-spending-spree-to-turn-club-into-Premier-League-title-contenders.html

${ }_{30}$ https://www.theguardian.com/football/blog/2016/apr/05/manchester-city-psg-champions-league-football-finance

${ }_{31} \mathrm{http://www.manutd.com/en/Club/FAQs/Club-Orientation/Question-1.aspx}$

32 http://news.bbc.co.uk/1/hi/business/4540939.stm

${ }^{33} \mathrm{http} / / /$ www.telegraph.co.uk/finance/newsbysector/banksandfinance/7083750/Manchester-United-opens-window-on-murky-world-of-leveraged-buy-outs.html

${ }^{34} \mathrm{http}: / /$ news.bbc.co.uk/sport1/hi/football/teams/m/man utd/4541093.stm

35 http://www.independent.co.uk/sport/football/premier-league/glazer-family-have-drained-1billion-from-manchester-united-10244576.html

${ }^{36} \mathrm{http://www.nufc.co.uk/page/Club/Home}$

${ }^{37} \mathrm{http}: / /$ www.chroniclelive.co.uk/sport/football/football-news/newcastle-united-boycott-big-questions-9068269

${ }^{38} \mathrm{http}: / /$ ashleyout.com/

${ }^{39} \underline{\text { http://www.bbc.co.uk/news/uk-15673793 }}$ 


\begin{tabular}{|c|c|}
\hline \multirow{2}{*}{$\begin{array}{l}\text { Norwich City Football Club } 40 \\
\text { (NCFC) }\end{array}$} & $\begin{array}{l}\text { Delia Smith and Michael Wynn- } \\
\text { Jones }\end{array}$ \\
\hline & Michael Foulger \\
\hline & Individual shareholders \\
\hline
\end{tabular}

\begin{tabular}{|l|l|}
\hline $76 \%$ & UK \\
\hline $23 \%$ & UK \\
\hline $1 \%$ & \\
\hline
\end{tabular}

Owner Delia Smith is often cited as defending the identity of the Club, particularly from wealthy takeovers. Although competitive life in the EPL is much determined by the financial power of Clubs, NCFC adopt a debt free strategy for sustainability ${ }^{41}$. No protests recorded. Equilibrium. No reports of detachment, disenchantment or protest.

Sheffield United Football Club ${ }^{42}$ H.R.H. Prince Abdullah bin Mosaad bin Abdulaziz Al Saud $\quad 100 \%$ Saudi Arabia

Recent acquisition of the majority shareholding was completed in 2019 after a drawn out tussle for ownership with previous co-owner ${ }^{43}$. Equilibrium. Yet, recent history of detachment, disenchantment and protest.

Southampton Football Club ${ }^{44}$ (SFC)

Gao Jisheng, Jinga Gao and Katharina Liebherr
Hong Kong and Germany

In 2009 entrepreneur Markus Liebherr bought SFC and installed Nicola Cortese as Chairman, saving the Club from administration, having been relegated to the third tier division. Under their stewardship the Club rose to the EPL after back to back promotions. Markus died in 2010 and his daughter Katharina inherited to Club. Amidst their indifferences about the running of the Club Cortese, who had spearheaded the Club from their takeover to 2014 left the Club. Substantial investment is annually loaned to the Club from the owner, while she keeps a low public profile. In 2017 Gao's invested and attained controlling stake of $80 \% 45$. Protests were rife prior to Liebherr's takeover and have recently resurfaced against the current regime and financial constraints ${ }^{46}$. Disequilibrium. Detachment, disenchantment and protest.

\begin{tabular}{l|lll|l}
\hline Tottenham Hotspur Football Club & & Joe Lewis & $70.6 \%$ & UK \\
(THFC) & & Daniel Levy & $29.4 \%$ & UK
\end{tabular}

THFC have recently moved to a new stadium. Part of the move was based on a strategy that would increase the financial income to the Club in an attempt to create a level playing field to the Clubs they compete with in the EPL (namely; LFC, AFC, CFC, MCFC \& MUFC). However, some fans have run out of patience with the lack of accountability shown from the club and they are detached and disenchanted with the lack of investment/transparency in the running of the Club (one could say is that fans wish for an outsider to invest and take the club to the next level of financial investment to align with other top clubs. This has been an on-going issue for THFC fans, who have been complaining about this since they turned PLC in $1983^{48}$. The resentment towards the board is echoed by many but in the words of one THFC fan: "makes me sick how clubs have no empathy with the common fan. would make you wonder how these guys get into these positions where they have to deal with the public. Is so obvious that they [the owners] think that they can treat fans like shit because they will always come back because of their love for the club" 49 . The quote has deep resentment for the owners of THFC but also makes a more general point beyond his own club. There's a sense that this is not an isolated case. Additionally, the quote emphasises the point that fans come back - as fans see the club as theirs, the owners may change but the fan sticks with the club. Disequilibrium. Detachment, disenchantment and protest.

1.amazonaws.com/company/00/15/40/44/654 AA $30 \quad 06 \quad 2015$ Annual Accounts.pdf?AWSAccessKeyld=AKIAJWDGFR4OWEUDNJRQ\&Expires=1449596913\&Signature=dLe94uguVqScwZ6ZPWT\%2BQSDZdfg\%3D ${ }^{41} \mathrm{http}$ ///norwichcity.myfootballwriter.com/2014/05/30/a-sound-financial-footing-is-one-thing-it-would-take-investment-beyond-the-pale-to-take-city-to-the-next-level/

42 https://www.sufc.co.uk/news/2019/october/key-personnel/

${ }^{43}$ https://www.dailymail.co.uk/sport/football/article-7468581/Sheffield-United-owner-Kevin-McCabe-FORCED-sell-share-club-Prince-Abdullah.html

${ }^{44}$ http://www.saintsfc.co.uk/club/Orientation/

45 https://www.independent.co.uk/sport/football/premier-league/southampton-news-sale-gao-jisheng-owner-ralph-hasenhuttl-arsenal-epl-a9213571.html

${ }^{46} \mathrm{https}: / /$ www.independent.co.uk/sport/football/premier-league/southampton-news-sale-gao-jisheng-owner-ralph-hasenhuttl-arsenal-epl-a9213571.html

${ }^{47} \mathrm{http://www.tottenhamhotspur.com/the-club/investor-relations/shareholder-faqs/}$

${ }^{48} \mathrm{http}: / /$ www.express.co.uk/sport/football/602546/Tottenham-transfer-news-Mauricio-Pochettino-Daniel-Levy

${ }^{49} \mathrm{http://www.spurs.vitalfootball.co.uk/article.asp?a=79914 \# ixzz4ScnCKbph}$ ttp://mc.manuscriptcentral.com/ijebr 


\section{Watford Football Club 50}

(WFC)

Gino Pozzo

$100 \%$

Italy

The WFC owner Pozzo owns a portfolio of clubs - one in Italy and another in Spain. Taking over WFC in 2012 when they were threatened with administration, Pozzo is renowned for the family shared scouting network and loaning players between his three teams ${ }^{51}$. Equilibrium. Yet, recent history of detachment, disenchantment and protest.

West Ham United Football Club 52 (WHUFC)

\begin{tabular}{|l|l|l|}
\hline David Sullivan & $51.1 \%$ & UK \\
\hline David Gold & $35.1 \%$ & UK \\
\hline Individual shareholders & $13.8 \%$ & \\
\hline
\end{tabular}

Entrepreneurs Sullivan and Gold took over WHUFC in 2010, saving the Club from administration. As lifelong fans they suggested they had made a bad business mistake in buying a Club in such debt - yet promised Champions League football and a new ground ${ }^{53}$. Season 2016/17 saw them start playing at their new stadium, the former London 2012 Olympics Games stadium. Fan protests against the owners has been commonplace, fans are unhappy about the unatmospheric stadium and direction of the club under the current stewardship ${ }^{54}$ Disequilibrium. Detachment, disenchantment and protest.

Wolverhampton Wanderers Football Club $^{55}$ (WWFC)

\section{Fosun Group}

$100 \%$

China

At WWFC there have been several decades of mismanagement and unscrupulous owners. The club went into receivership in 1982 and under the Bhatti brothers between 1982 and 1986 saw the club relegated to the fourth tier division for the first time in their history ${ }^{56}$. After several subsequent years of different owners, the Fosun Group of three shareholders ${ }^{57}$ bought the club in 2016 . Rising to the EPL with recent success since the takeover has created a period of stability. No recent protests recorded.

Equilibrium. Yet, recent history of detachment, disenchantment and protest.

${ }^{50} \mathrm{http}: / / \mathrm{www}$. watfordfc.com/club/contacts/

${ }^{51} \mathrm{http}: / /$ www.sport.co.uk/football/why-what-the-pozzo-family-is-doing-at-watford-udinese-gran/3815717/\#F3RrojuBH2IMAwLH.97

${ }^{52}$ http://www.whufc.com/Club/Corporate-Information/Orientation

${ }^{53} \mathrm{http}: / /$ www.theguardian.com/football/2010/jan/19/sullivan-gold-west-ham-takeover

54 https://www.standard.co.uk/sport/football/west-ham-fans-protest-owners-southampton-a4371116.html

${ }^{55} \mathrm{https://www.standard.co.uk/sport/football/west-ham-fans-prot}$

${ }^{56}$ https://www.bbc.co.uk/sport/football/21589401

${ }^{57}$ https://www.wolves.co.uk/club/about-us/directors-profiles/ 
English Championship (Season 2019/20)

\begin{tabular}{|l|l|l|l|}
\hline \multicolumn{1}{|c|}{ Football Club } & \multicolumn{1}{|c|}{ Controlling Party/s } & \multicolumn{1}{c|}{ Stake } & \multicolumn{1}{c|}{ Origins } \\
\hline $\begin{array}{l}\text { Barnsley Football Club } \\
\text { (BarnFC) }\end{array}$ & Pacific Media Group & $80 \%$ & International \\
\cline { 3 - 4 } & Patrick Cryne & $20 \%$ & UK \\
\hline
\end{tabular}

BarnFC are owned by and local businessman Patrick Cryne. Cryne sold $80 \%$ of the club in 2017. Supporter protests over the sale of the club to PMG have been happening since that time ${ }^{58}$.

Disequilibrium. Detachment, disenchantment and protest.
Birmingham City Football Club 59
(BirmCFC)

\section{Seun Cho Hung, Vong Pech, Lei} Sutong

$100 \% \quad$ China

BCFC have deep ownership concerns. The Club fell into receivership in March 2015 with a precarious history. Previous owner Yeung became the majority shareholder in 2009, who's currently in prison in Hong Kong for money laundering. Although stepping down as President, he was the majority shareholder, alongside Wang Lei, Yeung's brother-in-law ${ }^{60}$ until Hung, Pech and Sutong took over in $2015^{61}$. Protests by supporters have become commonplace in the past ten years ${ }^{62}$ Disequilibrium. Detachment, disenchantment and protest.

\begin{tabular}{l|l}
$\begin{array}{l}\text { Blackburn Rovers Football Club63 } 64 \\
\text { (BRFC) }\end{array}$ & $\begin{array}{l}\text { Banda Venkatesh and } \\
\text { Banda Balaji Rao }\end{array}$
\end{tabular}

There was outcry from BRFC fans when the Club was sold to the Venki's in 2010. Despite the promises of protecting the legacy of the previous fan owner Jack Walker, who took the Club from the lower divisions to the EPL title in 1995, the Venki's promise of investment in new players did not materialise and the Club haemorrhaged players and were relegated from the EPL ${ }^{65}{ }^{66}$. Fans have set up their own website, venkysout.com, which captures fans concerns, with news articles, videos and demonstration plans. The Venky's ownership has been described as 'toxic' and Blackburn Rovers FC Action Group have described the board as, "incapable, powerless or completely absent from duty" in calling for their immediate resignation ${ }^{67}$. In a fan poll by Rovers Trust at the end of the 2015-6 season, $40 \%$ of fans said they were not going to renew their season tickets, $90 \%$ said they would return under different ownership. An article stated, "Football, above any other industry, feeds on the relationship between club and supporters [fans]. If you break this, you are left with nothing. The Rovers Trust continues to seek communication and dialogue with the owners of Blackburn Rovers, who have made no attempts to make contact with the trust since they took over the club. Fans rightly feel alienated from their club right now, but are sending out a message that they will wholeheartedly support new owners." ${ }^{2} 8$ Disequilibrium. Detachment, disenchantment and protest.

\begin{tabular}{|c|c|c|c|}
\hline \multirow{3}{*}{$\begin{array}{l}\text { Brentford Football Club } \\
\text { (BrentFC) }\end{array}$} & Matthew Benham & $96.23 \%$ & UK \\
\hline & $\begin{array}{l}\text { Brentford Football Community } \\
\text { Society Limited }\end{array}$ & $1 \%$ & \\
\hline & Individual shareholders & $2.77 \%$ & \\
\hline \multicolumn{4}{|c|}{$\begin{array}{l}\text { BFC are an interesting case, Benham is a lifelong fan - and has invested }(£ 43 \mathrm{~m}) \text { in the Club since his takeover } \\
\text { in } 2012 \text {. He states "The intention is to found a dynasty of the sort that football used to be familiar with in the } \\
\text { days before so many foreign owners"70. Their previous ownership is also interesting - they were fan owned, by } \\
\text { Bees United. They took over in } 2006 \text { inheriting debts of £8m from fan owner Ron Noades } \text { f }^{71} \text {. Interestingly the } \\
\text { investors behind Bees United were five fans, one was Benham - they all became Directors }{ }^{72} \text {. No protests } \\
\text { recorded. Equilibrium. No reports of detachment, disenchantment or protest. }\end{array}$} \\
\hline
\end{tabular}

${ }^{58} \mathrm{http}: / /$ barnsleyfc.org.uk/threads/protest-in-the-21st-minute.284278/

${ }^{59} \mathrm{http} / / / \mathrm{www}$.bcfc.com/documents/birmingham-city-plc-shareholder-breakdown-fl-rules-01072015101-2520445.pdf

60 http//www oftenpartisan co uk/archives/13021/who-is-wang-teihtml

${ }_{61} \mathrm{http://wwW.oftenpartisan.co.uk/archives/13021/who-is-wang-lei.html}$

62 https://www.birminghammail.co.uk/sport/football/football-news/birmingham-city-protest-owner-forest-17672820

63 http://www.rovers.co.uk/club/contactus/

${ }^{64} \mathrm{https}$ ://companycheck.co.uk/company/00053482/THE-BLACKBURN-ROVERS-FOOTBALL-AND-ATHLETIC-LIMITED/group-structure

65 http://www.theguardian.com/football/2010/nov/19/venkys-completes-takeover-blackburn-rovers

${ }^{66} \mathrm{http}$ ://www.independent.co.uk/sport/football/premier-league/venkys-takeover-threatening-to-end-in-tears-at-rovers-2276245.html

${ }^{67}$ http://www.fsf.org.uk/latest-news/view/blackburn-is-toxic-brand-under-venkys-ownership-say-fans

68 http://www.roverstrust.com/2016/05/24/first-major-rovers-season-ticket-survey-reveals-massive-discontentment-major-opportunity/

${ }^{69} \mathrm{http://www.roverstrust.com/2016/05/24/first-major-rovers-season-ticket-survey-reveals-massive-disco}$

${ }^{69} \mathrm{http://www.brentfordfc.co.uk/documents/bfc-statutory-final-accounts-may-2013277-1336709.pdf}$ http://www.standard.co.uk/sport/football/brentford-owner-matthew-benham-every-championship-club-wants-to-get-into-the-premier-league-and-we-9336176.htm

${ }^{71} \mathrm{http://www.standard.co.uk/sport/football/brentford-owner-matthew-benham-} \mathrm{http} / /$ www.brentfordtw8.com/default.asp?section=info\&page=ebfc50a.htm

72 http://www.beesunited.org.uk/trust-news/190-takeover-q-a-a-part-one 1 v15-190 $/ / m$. manuscriptcentral.com/ijebr 
Bristol City Football Club ${ }^{73}$ (BristCFC) Stephen Lansdown $94.06 \%$ Keith Dawe Individual shareholders $2.36 \%$ $3.58 \%$

Entrepreneur Lansdown also own Bristol Rugby and Bristol Flyers (Basketball), he is a lifelong fan from Bristol. He became involved in BCFC in 1996 and became majority shareholder in 2002, yet stepping down as Chairman in $2011^{74}$. He has invested both in team and ground facilities. No protests recorded. Equilibrium. No reports of detachment, disenchantment or protest.

\section{Cardiff City Football Club 75 (CCFC)}

\begin{tabular}{|l|l|l|}
\hline $\begin{array}{l}\text { Tan Sri Dato' Seri Vincent Tan } \\
\text { Chee Yioun }\end{array}$ & $87.5 \%$ & Malaysia \\
\hline Individual shareholders & $12.5 \%$ & \\
\hline
\end{tabular}

After a much troubled history of unscrupulous owners ${ }^{76} 7778$ between $2000-2020$, the Club has seen more than its fair share of disequilibrium. None no-more-so than owner Peter Risdale, two charges under the Consumer Protection from Unfair Trading Regulations 2008 and one under the Fraud Act 2006 for defaulting on a promise to fans who bought a 10 year season ticket - suggesting the money would go on new players ${ }^{79}$. At the end of the 2010 season, the Club was sold to Malaysian investors accrued $30 \%$ of shares ${ }^{80}$. Consortium leader Tien Ghee, became chairman and U-Juin Tan as Non-Exec Director, with Vincent Tan, named as the backer behind the move - becoming more prominent in 2012. In 2012 against many of the fans wishes and Club heritage ${ }^{81}$, Tan changed the Club colours and re-branded the crest. What fans found problematic was the validity of a so called comprehensive review conducted by the owners before changing the colours and logo when $99 \%$ of the fans in the stadium wear blue (in keeping with tradition). Secondly, the drive to exploit overseas markets at the cost of club heritage was considered disrespectful if not naïve to the home-based fan. Tan suggested: "In Asia, red is the colour of joy, red is the colour of festivities and of celebration. In Chinese culture, blue is the colour of mourning." 82. However, should one persons' taste and opinion ride roughshod through 100 years of history? In 2015 Tan reversed his decision, Cardiff are back playing in blue. As at the time of writing Tan is still the owner, he suggests he has learnt from the experience ${ }^{83}$. The episode highlights the lack of understanding of the strength of feeling fans attach to social and cultural capital, highlighting Tan as an 'outsider'. Disequilibrium. Detachment, disenchantment and protest.

\begin{tabular}{l|l|l|l}
$\begin{array}{l}\text { Charlton Athletic Football Club } \\
\text { (CAFC) }\end{array}$ & East Street Investments & $100 \%$ & UAE
\end{tabular}

Under the previous five -year regime of Roland Duchatelet supporter protests were rife ${ }^{85}$. CAFC are current in limbo, new owners acquired the club in November 201986. However, in March 2020 the main investor reportedly pulled out, the EFL have not approved the takeover and in April 2020 the EFL announced an investigation into the takeover by East Street Investments ${ }^{87}$. Supporters are again, left outraged by the turmoil. ${ }^{88}$ Disequilibrium. Detachment, disenchantment and protest.

Derby County Football Club 89 (DCFC) Mel Morris $100 \%$ UK

DCFC have a fan owner in Morris, who took control in September 2015. The Club is reportedly well run, having been in receivership a decade before and also for a short period under American ownership ${ }^{90}$. No recent protests recorded. Equilibrium. Yet, recent history of detachment, disenchantment and protest. 


\section{Fulham Football Club ${ }^{91}$}

(FFC)

Shahid Khan

$100 \%$

USA

Khan, the owner of Jacksonville Jaguars (NFL), bought FFC in 2013. With fans re-adjusting to life after the previous owner (Mohamed Al-Fayed) invested $£ 187$ million in the Club in his tenure ${ }^{92}$, taking the Club up four divisions and a decade in the EPL. Fans have questioned Khan's strategic role ${ }^{93}$. There are protests against ticket prices and discontent of the owner ${ }^{94}$ Disequilibrium. Detachment, disenchantment and protest.

Phil Hodgkinson
$100 \%$ (HTFC)

Hodgkinson acquired HTFC in May 2019, from previous owner of the previous decade, Hoyle (now a Director). Both are lifelong fans, well-liked by fans ${ }^{96}$. No protests recorded.

Equilibrium. No reports of detachment, disenchantment or protest.

Hull City Football Club ${ }^{97}$ (HCFC) Allam Family $100 \%$ Egypt HCFC were almost wound up, relegated out of the football league after a series of unscrupulous owners in the 1990's, including David Lloyd - the Leisure Centre entrepreneur. In 2010 with the investment of new owner Egyptian born local entrepreneur Assem Allam, the Club were rescued from administration, Allam bailing the club out of a $£ 35$ million of debt ${ }^{98}$. He suggested on his takeover that; "I have been in this area for 42 years and I have built my business in the area, " adding, "I think it's time to pay back the area - Hull City are important to the area." 87 Suggesting the entrepreneur is himself embedded in community life - part of the culture and social fabric of Hull as a City. In April 2013 Allam changed the club name at Companies House to 'Hull City Tigers Limited' and instigated new branding on signs around the ground, kit design and merchandise. Allam outraged and alienated fans by proposing a name change - from 'Hull City Association Football Club' (the name they had when they formed in 1904) to 'Hull Tigers'. Allam stressed... "Hull City is irrelevant. My dislike to the word City is because it is common... City is a lousy identity",..... adding "I cannot afford to run the club by fans' feelings"99. There are a number of issues that have angered fans. Firstly the club seeks to forgo its identity as a 'city' and an 'association football club' (the word 'association' refers to membership of the FA, the English Football Association - a term that many clubs (at Hull City since 1904) have in their name from the time of incorporation, which means a lot to English Football heritage, fan heritage and football culture); secondly, that Allam would appear to see the club as a commodity to galvanise a fan base from other parts of the world; thirdly, that the fans were not consulted prior to the application for a name change and finally, and probably the biggest omission is their acknowledgement to the fact that they are not football people - but business people. Yet they ask the fans to trust their judgement. Allam's motivation would appear to be the financial rewards of the globalisation of EPL football and the associated (club) brands. Protests have been ongoing since 2013, with a fan campaign with the slogan, "Hull City AFC: A $\underline{\text { CLUB }}$ not a brand" with fans funding posters and leaflet drops at the stadium on match days. Concurrently, The Independent newspaper covered the story, with a comment from Allam suggesting that fans who sing "City till we die", could "die as soon as they want"100. The fans reportedly sang in response, "We're Hull City, we'll die when we want" ${ }^{101}$. The Football Supports Federation got behind, as did Hull City fans, in campaigning to save the name, whilst other club fans around the globe stood in support. Following the proposal, the name change went through two rounds of review (one in 2013 and one in 2015) with the Football Association's Membership Committee before being rejected (by more than 65\% and 69\% per vote) due to the wave of opinion against the change. As at the time of writing the Allam family are still the owners of the club and whilst they lost the name change the team branding is no longer 'City', no longer 'AFC' and the website is branded both as simply 'Hull City 1904' and 'Hull City Tigers Limited'. Disequilibrium. Detachment, disenchantment and protest. 
Leeds United Football Club ${ }^{102}$ (LUFC)

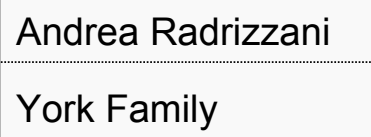

$90 \%$ Italy

After many problematic years of (unscrupulous) ownership churn, they are currently owner by Italian Radrizzani. He acquired the club from Cellino who took over in 2014, after initially being blocked by the Football League under their 'fit and proper' rules ${ }^{103}$, later suspended by the league following his second conviction in Italy for tax evasion ${ }^{104}$. Cellino made his mark on LUFC, sacking five managers in 17 months, as well as numerous other 'incidents' 105 . Radrizzani seems to have eased the situation and no current protests reported. Equilibrium. Yet, recent history of detachment, disenchantment and protest.

Luton Town FC (LTFC) ${ }^{106}$

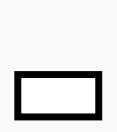

Paul Ballantyne
Individual shareholders

$80 \%$ $20 \%$

Fan entrepreneur Ballantyne is the majority shareholder but the club has active shareholders and directors which make up the club officials. No protests recorded.

Equilibrium. No reports of detachment, disenchantment or protest.

\begin{tabular}{l|l|l|l|l} 
Middlesbrough Football Club 107 & Steve Gibson & $75 \%$ & UK \\
(MidFC) & $\square$ & Michael O'Neill & $25 \%$ & UK
\end{tabular}

Fan entrepreneur Gibson has been owner for some 20 years. Overseeing saviour from liquidation in 1986, a move to a new stadium in 1995 and their first major trophy in 2004 ${ }^{108}$. No protests recorded.

Equilibrium. No reports of detachment, disenchantment or protest.

Millwall Football Club (MillFC)

\begin{tabular}{|l|l|l|}
\hline John Berylson & $70 \%$ & UK \\
\hline $\begin{array}{l}\text { Company and Individuals } \\
\text { shareholders }\end{array}$ & $30 \%$ & UK \\
\hline
\end{tabular}

US entrepreneur Berylson is the majority shareholder but the club has individual shareholders and directors (fans) which make up the club officials. No protests recorded.

Equilibrium. No reports of detachment, disenchantment or protest.

\section{Nottingham Forest Football Club}

(NFFC)

\section{Evangelos Marinakis}

Entrepreneur Marinakis bought NFFC from the Kuwait based Al Hasawi family in 2017 after five year of fan protests and turmoil, with the club sacking seven managers in their reign ${ }^{109}$. Marinakis has some baggage, with the Guardian reporting on his past ${ }^{110}$, yet no supporter protests are recorded during his directorship so far. Equilibrium. Yet, recent history of detachment, disenchantment and protest.

\section{Preston North End Football Club ${ }^{111}$ (PNEFC)}

\section{Trevor Hemmings} $100 \%$

\section{UK}

Philanthropist/entrepreneur and fan Hemmings bought PNE in 2010 and promotion to the Championship has maintained a trusting relationship with supporters ${ }^{112}$. No protests recorded.

Equilibrium. No reports of detachment, disenchantment or protest.

${ }^{102} \mathrm{http}: / /$ www.leedsunited.com/club-Orientation

${ }_{103} \mathrm{http}: / /$ www.yorkshireeveningpost.co.uk/sport/leeds-united/latest-lufc-news/leeds-united-cellino-will-take-Orientation-fight-to-the-european-courts-1-7574075

104 http://www.theguardian.com/football/2015/nov/26/massimo-cellino-leeds-united-two-bans

$105 \mathrm{http}: / /$ www.theguardian.com/football/2015/nov/26/massimo-cellino-leeds-united-two-ban

${ }^{106}$ https://www.lutontown.co.uk/company-details/

$107 \mathrm{https}: / /$ companycheck.co.uk/company/02991817/THE-GIBSON-ONEILL-COMPANY-LIMITED/group-structure

$108 \mathrm{http} / / / \mathrm{www} . \mathrm{mfc}$. premiumtv.co.uk/page/club/whos-who/0, 1 2313762,00.html

${ }_{109} \mathrm{http://www.mfc.premiumtv.co.uk/page/club/wh}$ https://www.bbc.co.uk/sport/football/42528150

${ }_{110}^{109} \mathrm{https://www.bbc.co.uk/sport/football/42528150}$ https:/www.theguardian.com/football/2017/may/18/nottingham-forest-evangelos-marinakis-takeover

${ }^{111} \mathrm{https}$ ://www.theguardian.com/football/2017/may/18/nottingham-forest-evangelos

${ }_{112} \underline{\text { http://www.insidermedia.com/insider/northwest/111990-debt-restructure-preston-north-end/ }}$ nttp:/mc.malhuscriptcentral.com/ijebr 


\begin{tabular}{|l|l|l|l|}
\hline $\begin{array}{l}\text { Queens Park Rangers Football } \\
\text { Club } 113 \\
\text { (QPRFC) }\end{array}$ & $\begin{array}{l}\text { Tan Sri Tony Fernandes, } \\
\text { Kamarudin Bin Meranun and } \\
\text { Ruben Emir Gnanalingam }{ }^{114}\end{array}$ & $66 \%$ & Malaysia \\
\hline & \begin{tabular}{l} 
Lakshmi Mittal \\
\hline
\end{tabular} & $33 \%$ & India \\
\hline
\end{tabular}

Following a turbulent decade prior to Fernandes's takeover of the club in 2011 QPR have sought to consolidate their league position and build on a sustainable business model ${ }^{115}$. However, Fernandes's ability and knowledge of football is being questioned in the period that has seen five new managers and no return for the financial outlay of players during his tenure ${ }^{116}$ Some protests noted about the churn of managers but no momentum. Equilibrium. Yet, recent history of detachment, disenchantment and protest.

\begin{tabular}{l|l|l|l}
$\begin{array}{l}\text { Reading Football Club } \\
\text { (RFC) }\end{array}$ & Yongge Dai & $95.38 \%$ & China \\
\hline
\end{tabular}

Following the rise of RFC under the stewardship of previous long term local owner John Madejski from 1990 to 2012, a Russian Anton Zingarevich, followed by a Thai consortium each took ownership of the Club. These times were turbulent, yet Madejski remained as Chairman and so the fans stayed loyal to his decisions, despite the switch in investors ${ }^{118}$. Madejski has now stepped down and Dai's RFC were under a recent transfer embargo for financial irregularities ${ }^{119}$, however the fans show no signs of discontent. No protests recorded. Equilibrium. Yet, recent history of detachment, disenchantment and protest.

Sheffield Wednesday Football

Club $^{120}$

(SWFC)

\section{Dejphon Chansiri}

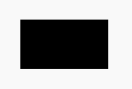

Chansiri's reign began in early 2015 and seems to have endured himself to the fans with investment in new players, manager and an entertaining style of football - all of which were outlined when he took over the Club $^{121}$. He has also engaged fans in designing a new crest $^{122}$. However, more recently fans are beginning to question the fulfilment of his plans ${ }^{123}$ Disequilibrium. Detachment, disenchantment and protest.

\section{Stoke City Football Club ${ }^{124}$ (SCFC)}

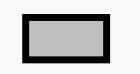

The Coates Family

$100 \%$

UK

SCFC are owned by the Coates family, father Peter and daughter Denise. Peter was born in Stoke and is a lifelong fan. Although a previous owner of the Club, Peter re-bought the Club in 2006 and oversaw their rise from the $3^{\text {rd }}$ tier of the football pyramid to the EPL ${ }^{125}$. Substantial investment is annually loaned to the Club from the family. The orientation would appear to be based on local loyalty to the area and the support of their local football team, whilst promoting other business interests; the Club bares stadium and shirt sponsorship with Coates family business, Bet365, which is a gambling company based in Stoke. The fans appear to share an alignment of interests with the club (coded white in Figure 3), with no protest against their vision and values for the club. Equilibrium. Yet, recent history of detachment, disenchantment and protest.

${ }^{113}$ http://www.qpr.co.uk/club/info/company-details/index.aspx\#VX7xeRpElO7TSri6.99

${ }_{114}$ Each owns a third of the stake: $\mathrm{https}: / /$ companycheck.co.uk/company/08569701/RANGERS-DEVELOPMENTS-LTD/group-structure

$115 \mathrm{http}: / /$ www.theguardian.com/football/2011/aug/18/tony-fernandes-qpr-takeover

${ }_{116} \mathrm{http} / / /$ www.independent.co.uk/sport/football/premier-league/tony-fernandes-and-mike-ashley-have-both-damaged-their-respective-clubs-but-in-different-ways-glenn-10254485.html

${ }_{117}$ https://www.readingfc.co.uk/company-details/

${ }_{118} \mathrm{http://www.fcbusiness.co.uk/news/article/newsitem=3319/title=reading+to+partner+with+thai+consortium}$

${ }_{119} \mathrm{https}: / / \mathrm{www}$. getreading.co.uk/sport/football/transfer-news/what-soft-embargo-means-reading-16461879

${ }^{120} \mathrm{http://www.swfc.co.uk/club/company} \mathrm{details/index.aspx \# vpr4yVxhTZGDJ8j2.99}$

121 http://www.skysports.com/football/news/11703/10116236/watch-sheffield-wedednesday-chairman-dejphon-chansiri-talks-transfers

122 http://www.thestar.co.uk/sport/football/sheffield-wednesday/owls-on-crest-of-a-wave-after-chansiri-unveils-new-sheffield-wednesday-badge-1-7693889

${ }_{123} \mathrm{http://www.thestar.co.uk/sport/football/sheffield-wednesday/owls-on-crest-of-a-wave-after-chansiri-unveils-new-sheffield-wednesd}$

${ }^{124} \frac{\mathrm{https}: / / \mathrm{www} . \text { footballtransfertavern.com/cham } / / \text { www.stokecityfc.com/club/whoswho/ }}{\mathrm{http}}$

125http://www.publications.parliament.uk/pa/cm201012/cmselect/cmcumeds/792/79208.htm 1 http:/mc.manuscriptcentral.com/ijebr 
Swansea City Association Football

Club $^{126}$

(SCAFC)

\begin{tabular}{|l|l|l|}
\hline $\begin{array}{l}\text { Stephen Kaplan \& Jason Levien } \\
\text { Swansea City Supporters Society } \\
\text { Ltd }\end{array}$ & $68 \%$ & USA \\
\hline $\begin{array}{l}\text { Individual Shareholders } \\
\text { 21.1\% }\end{array}$ & \\
\hline
\end{tabular}

SCAFC are a unique football club in English football, as a fan group has a $21 \%$ share in the Club. However, recent acquisition by US investors Kaplan (Chair of Memphis Grizzlies NBA team) and Levien (DC United partner) who bought a controlling stake from previous Chairman and fan owner Jenkins and other fan Directors has been less transparent than the Supporters Society would wish ${ }^{127}$. Fans questioned the decision of the sale of majority ownership to US investors, stating they had been bypassed in the sale of shares, despite their stake in the Club, with fan representative standing down from the Board in protest. The sense of injustice to the fans has been heard inside the stadium, with reports that fans sang "we want our club back" and "You greedy bastards, get out of our Club"128. In a fans poll December 2016, 45\% of fans agreed that the US investors were going to "asset strip and bleed the club dry"129. Disequilibrium. Detachment, disenchantment and protest.

\begin{tabular}{|c|c|c|c|}
\hline West Bromwich Albion Football & Guochuan Lai & $87.8 \%$ & China \\
\hline (WBAFC) & Individual shareholders & $12.2 \%$ & \\
\hline
\end{tabular}

The sale of WBAFC to Chinese investor Lai ended several years of speculation of the sale of the Club from previous local owner and fan, Jeremy Peace. Under the Chinese Government's strategic agenda to make their nation a powerful player in world football, as outlined in their Football Reform and Development plan, the investment is based on Lai's links with town planning and ideas for replicating the academy system at WBA ${ }^{131}$. Phillips (2016) claims Chinese investment in European football (including Spain, Italy and France) over the previous 6 months has surpassed $(£ 460 \mathrm{~m})$, yet this excluded the reported $£ 200 \mathrm{~m}$ Lai paid for almost $88 \%$ of WBAFC. The fans appear content with the new owner, with no protests evident, despite Lai's vast wealth he's reportedly constrained by balancing financial fair play rules ${ }^{132}$. Equilibrium. No reports of detachment, disenchantment or protest.

Wigan Athletic Football Club ${ }^{133}$ (WAFC)

\section{In Administration}

WAFC was acquired by IEC in November 2018 after two decades under the ownership of local fans the Whelan family, the majority of that with David Whelan, passing on to his grandson David Sharpe in $2015^{134}$. In May 2020 the club were sold to Next Leader Fund, only for the club to be put in administration on the $1^{\text {st }}$ July $2020^{135}$. Disequilibrium. Detachment, disenchantment and protest.

$126 \mathrm{http}: / /$ www.swanseacity.net/club/whos who/

${ }_{127} \mathrm{http} / / /$ www.swanstrust.co.uk/2016/07/22/trust-ready-for-detailed-discussions-with-new-swans-owners/

${ }_{128} \mathrm{http://www.walesonline.co.uk/sport/football/football-news/furious-swansea-city-fans-turn-12135845}$

${ }_{129} \mathrm{http} / / /$ www.fansnetwork.co.uk/football/swanseacity/members/Borojack/polls/1458/are-the-new-owners-going-to-take-the-club-forward-or-not

${ }_{130} \mathrm{http}: / /$ www.wba.co.uk/club/accounts Orientation/

${ }_{131} \mathrm{https}$ ://www.theguardian.com/football/2016/aug17/chinese-investment-west-brom-aston-villa-wolverhampton

132 https://twitter.com/swissramble/status/989044818243440640?lang=ar

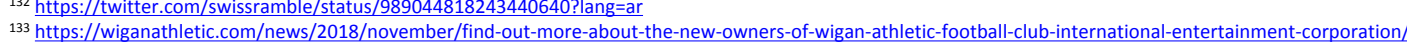

${ }_{134}^{133} \mathrm{https://wiganathletic.com/news/2018/ \text {november/ }}$ https://www.bbc.co.uk/sport/football/31711123

${ }_{135} \underline{\mathrm{https}: / / \mathrm{www} \cdot \mathrm{bbc} . \mathrm{ht} \mathrm{couk} / \mathrm{sport} / \text { football/31711123 }}$ 